Graphical Abstract Pictogram for Table of Contents
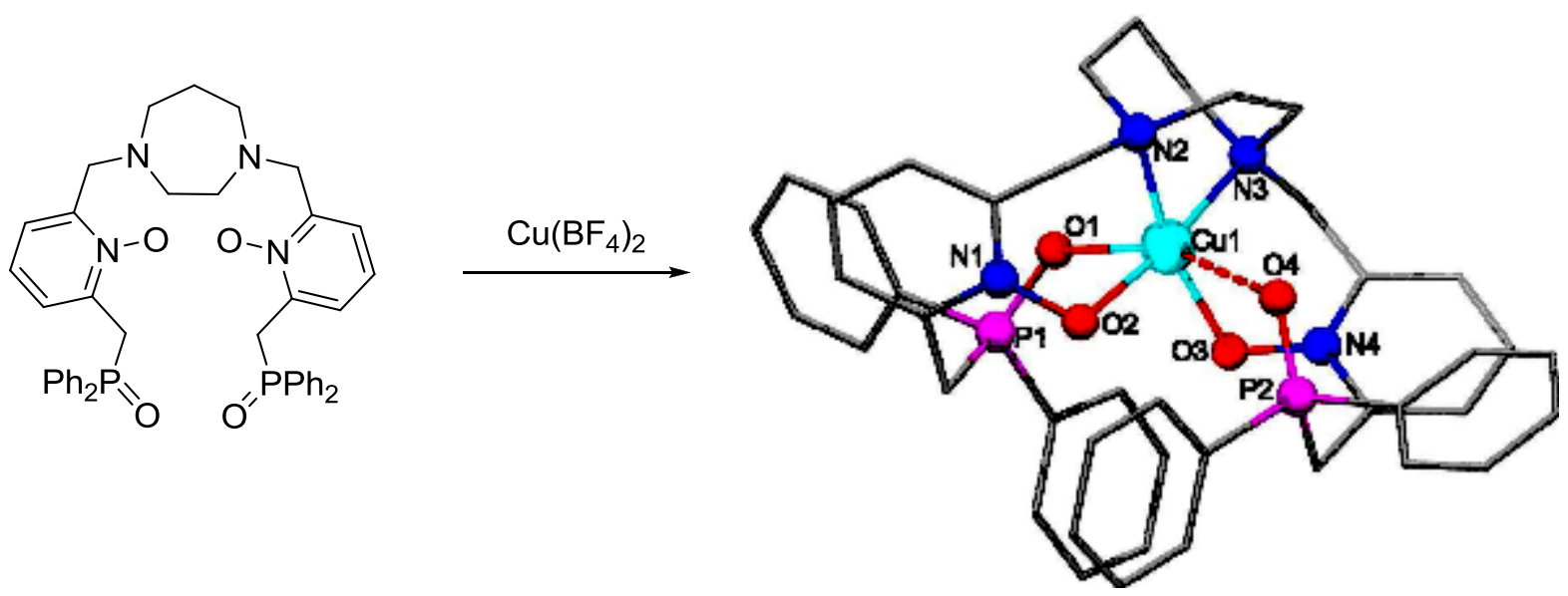


\section{Graphical Abstract Synopsis}

New pre-organized, hexadentate chelating phosphinoylmethyl pyridine and -pyridine N-oxide ligands, based upon a 1,4-diazepane platform, form stable complexes with $\mathrm{Ln}(\mathrm{III})$ and $\mathrm{Cu}(\mathrm{II})$ ions. Solvent extraction analyses for $\mathrm{Eu}(\mathrm{III})$ and $\mathrm{Am}(\mathrm{III})$ in nitric acid with the pyridine $\mathrm{N}$-oxide derivative show improved performance, at the highest nitric acid concentrations, compared to the parent bidentate phosphinoylmethyl pyridine $\mathrm{N}$-oxide ligand. 


\title{
Synthesis, selected coordination chemistry and extraction behavior of a (phosphinoylmethyl)pyridyl N-oxide-functionalized ligand based upon a 1,4-diazepane platform
}

Sabrina Ouizem ${ }^{\mathrm{a}, 1}$, Daniel Rosario Amorin ${ }^{\mathrm{a}, 2}$, Diane A. Dickie ${ }^{\mathrm{a}}$, Roger E. Cramer ${ }^{\mathrm{b}}$, Charles F. Campana ${ }^{\mathrm{c}}$, Benjamin P. Hay ${ }^{\mathrm{d}}$, Julien Podair ${ }^{\mathrm{e}}$, Laetitia H. Delmau ${ }^{\mathrm{e}}$ and Robert T. Paine ${ }^{\mathrm{a}, *}$

${ }^{\mathrm{a}}$ Department of Chemistry and Chemical Biology, University of New Mexico, Albuquerque, NM 87131, USA

${ }^{\mathrm{b}}$ Department of Chemistry, University of Hawai'i, Honolulu, HI 96822, USA,

${ }^{\mathrm{c} B r u k e r}$ AXS Inc., Madison, WI, 53711 USA,

${ }^{\mathrm{d}}$ Supramolecular Design Institute, 127 Chestnut Hill Road, Oak Ridge, TN 37830, USA

${ }^{\mathrm{e}}$ Nuclear Security and Isotope Technology Division, Oak Ridge National Laboratory, P.O. Box 2008, Oak Ridge, TN 37831, USA

\begin{abstract}
Syntheses for the new multidentate chelating ligands $((6,6$ '-((1,4-diazepane-1,4diyl)bis(methylene))bis(pyridine-6,2-diyl))bis(methylene))bis(diphenylphosphine oxide) (2) and 6,6'((1,4-diazepane-1,4-diyl)bis(methylene))bis(2-((diphenylphosphoryl)methyl)pyridine 1-oxide (3), based upon a 1,4-diazepane platform functionalized with 2-(diphenylphosphinoylmethyl)pyridine P-oxide and 2-(diphenylphosphinoylmethyl)pyridine N,P-dioxide fragments, respectively, are reported. Results from studies of the coordination chemistry of the ligands with selected lanthanide nitrates and $\mathrm{Cu}\left(\mathrm{BF}_{4}\right)_{2}$ are outlined, and crystal structures for two complexes, $[\mathrm{Cu}(\mathbf{2})]\left(\mathrm{BF}_{4}\right)_{2}$ and $[\mathrm{Cu}(\mathbf{3})]\left(\mathrm{BF}_{4}\right)_{2}$, are described along with survey $\mathrm{Eu}(\mathrm{III})$ and $\mathrm{Am}(\mathrm{III})$ solvent extraction analysis, for $\mathbf{3}$.
\end{abstract}

Keywords: Diazepane, Pyridyl, Phosphine oxide, Coordination Chemistry, Lanthanides, Cu(II) complexes, Solvent extraction, X-ray crystal structures 


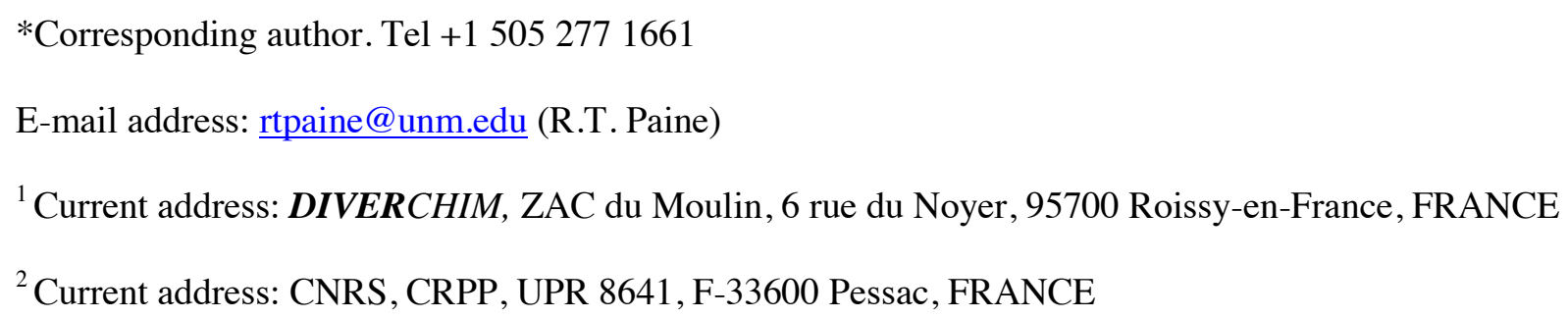

\section{Introduction}

Current practical needs for efficient chemical separation processes that result in selective recognition and binding of $f$-element ions in harsh environments is driving revived interest in the design and synthesis of new, robust multidentate organic chelating ligands [1-11]. In recent contributions we have described the development of several new multidentate phosphine oxide ligands that are based upon pyridine and pyridine N-oxide platforms including molecules of types A-E as shown in Figure 1. As expected, the coordination chemistry of these ligands with $f$-element ions has proven to be intriguing [12-25]. In particular, the N-oxide ligands (designated as NOPO ligands) of types $\mathbf{A}$ and $\mathbf{C}$, generally form bidentate $\mathrm{O}_{\mathrm{P}} \mathrm{O}_{\mathrm{N}}$ chelates while examples of $\mathbf{E}$ (designated as NOPOPO ligands) produce tridentate $\mathrm{O}_{\mathrm{P}} \mathrm{O}_{\mathrm{N}} \mathrm{O}_{\mathrm{P}}$ chelates. Furthermore, both ligand classes display unique solvent extraction performance [26-29]. The molecular structures of isolated solid-state coordination complexes and solvent extraction complexes in organic solutions typically contain two to four of these chelating ligands in the $f$-element ion inner coordination sphere. As a result, it is of interest to graft two or more of the chelating fragments onto a backbone that would position the collected donor centers for enhanced, pre-organized coordination interactions. Numerous possible backbones, with varying degrees of flexibility or rigidity, can be considered for this ligand construction objective, and several options are currently under study in our group. In particular, cyclic diamines such as piperazine, 1,4-diazacycloheptane, F, and 1,5diazacyclooctane rings have been used extensively as platforms to assemble various donor groups that provide pre-organized multidentate chelate structures. Directly pertinent to our studies, pyridyl-2-ylmethyl [30-38], pyridyl-2-yl-ethyl [35], quinoyl-2-yl-methyl [32] and imidazol-2-yl-methyl [36] fragments have been grafted onto one or more of these diamines, and their multidentate coordination 
interactions explored primarily with transition metal cations. In other cases, various carboxylic acid fragments have been attached to diamine platforms, and the coordination chemistry of these ligands with lanthanide ions examined with primary relevance to the development of MRI reagents [39-42]. In the present report, we describe the synthesis of two new ligands that contain two B (NPO) or C (NOPO) fragments appended to the 1,4-diazacycloheptane $\mathbf{F}(\mathrm{DACH})$ backbone $\left(\mathrm{R}^{\prime}=\mathrm{R}\right.$ ” $\left.=\mathrm{H}\right)$, along with selected coordination chemistry and preliminary screening of the $\mathrm{Eu}(\mathrm{III}) / \mathrm{Am}(\mathrm{III})$ extraction performance of the ligand containing the $\mathbf{C}$ fragments.

\section{[Insert Figure 1 here]}

\section{Experimental}

\subsection{Materials and general procedures}

Organic reagents (Aldrich Chemical Co.) and metal salts (Ventron) were used as received, and organic solvents (VWR) were dried by using standard methods. Unless noted otherwise, reactions were performed under a dry nitrogen atmosphere by using Schlenk methods. The 2,6-bis(chloromethyl)pyridine was

purchased or prepared as described previously [13]. Infrared spectra were recorded from $\mathrm{KBr}$ pellets on a Bruker Tensor 27 FTIR spectrometer. The FT-NMR spectra were recorded with Avance 300 and 500 spectrometers by using $\mathrm{Me}_{4} \mathrm{Si}\left({ }^{1} \mathrm{H}\right.$ and ${ }^{13} \mathrm{C}$ ) and $85 \% \mathrm{H}_{3} \mathrm{PO}_{4}$ as external chemical shift standards. Downfield shifts were assigned $+\delta$ values. The atom numbering systems used in the shift assignments for the new compounds are provided in the Supplementary Data. Mass spectra were obtained from the UNM Mass Spectrometry Center, and elemental analyses were performed by Galbraith Laboratories.

\subsection{Experimental procedures}

\subsubsection{Ligand syntheses}

2.2.1.1. 2-(diphenylphosphinoylmethyl)-6-(chloromethyl)pyridine (1a). Ethyl diphenylphosphinite (4.7 $\mathrm{mL}, 21.76 \mathrm{mmol}$ ) was combined with a solution of 2,6-bis(chloromethyl)pyridine (15.7 g, $89.18 \mathrm{mmol}$ ) 
[13] in $o$-xylene $(60 \mathrm{~mL})$ under a nitrogen atmosphere, and the mixture was stirred $\left(120^{\circ} \mathrm{C}, 2 \mathrm{~h}\right)$. After evaporation of solvent, the residue was purified by column chromatography (silica gel $(230 \mathrm{~g})$, $\mathrm{CH}_{2} \mathrm{Cl}_{2} / \mathrm{MeOH} 100 / 0$ to $97 / 3$ ) leaving 1a as a white powder. Yield: $6.64 \mathrm{~g}, 89 \%$. Mp 118-120 ${ }^{\circ} \mathrm{C}$. Single crystals of $\mathbf{1 a}$ were obtained by slow evaporation of a $\mathrm{CH}_{2} \mathrm{Cl}_{2} / \mathrm{Et}_{2} \mathrm{O}(10 / 90)$ solution. ${ }^{31} \mathrm{P}\left\{{ }^{1} \mathrm{H}\right\} \mathrm{NMR}$ $\left(121.5 \mathrm{MHz}, \mathrm{CDCl}_{3}\right): \delta=30.5 .{ }^{1} \mathrm{H} \mathrm{NMR}\left(300 \mathrm{MHz}, \mathrm{CDCl}_{3}\right): \delta=7.75-7.69\left(\mathrm{~m}, 4 \mathrm{H}, H_{9}\right), 7.52\left(\mathrm{t}, J_{H H}=7.8\right.$ $\left.\mathrm{Hz}, 1 \mathrm{H}, H_{4}\right), 7.46-7.33\left(\mathrm{~m}, 7 \mathrm{H}, H_{10,11}\right.$ and $H_{3}$ or $\left.H_{5}\right), 7.18\left(\mathrm{~d}, J_{H H}=7.8 \mathrm{~Hz}, 1 \mathrm{H}, H_{3}\right.$ or $\left.H_{5}\right), 4.42\left(\mathrm{~s}, 2 \mathrm{H}, H_{7}\right)$, $3.89\left(\mathrm{~d}, J_{H P}=14.4 \mathrm{~Hz}, 2 \mathrm{H}, H_{l}\right) .{ }^{13} \mathrm{C}\left\{{ }^{1} \mathrm{H}\right\} \mathrm{NMR}\left(75.4 \mathrm{MHz}, \mathrm{CDCl}_{3}\right): \delta=155.9\left(C_{6}\right), 152.4\left(\mathrm{~d}, J_{C P}=7.0\right.$ $\left.\mathrm{Hz}, C_{2}\right), 137.4\left(C_{4}\right), 132.3\left(\mathrm{~d}, J_{C P}=100.4 \mathrm{~Hz}, C_{8}\right), 131.8\left(C_{11}\right), 131.1\left(\mathrm{~d}, J_{C P}=9.5 \mathrm{~Hz}, C_{9}\right), 128.4\left(\mathrm{~d}, J_{C P}=\right.$ $\left.11.9 \mathrm{~Hz}, C_{10}\right), 124.2\left(\mathrm{~d}, J_{C P}=3.2 \mathrm{~Hz}, C_{5}\right), 120.8\left(C_{3}\right), 46.5\left(C_{7}\right), 40.9\left(\mathrm{~d}, J_{C P}=64.0 \mathrm{~Hz}, C_{1}\right) . \mathrm{IR}\left(\mathrm{KBr}, \mathrm{cm}^{-}\right.$ $\left.{ }^{1}\right): v=3057,2923,1612,1589,1575,1483,1455,1433,1397,1293,1268,1249,1225,1200\left(v_{\mathrm{P}=\mathrm{O}}\right), 1161$, $1118,1084,1066,1024,992,963,858,827,813,753,734,714,699,690,618,575,543,519,490,452$, 435, 410. HRMS (ESI): $m / z(\%)=342.0826(100)\left[\mathrm{M}+\mathrm{H}^{+}\right] . \mathrm{C}_{19} \mathrm{H}_{18} \mathrm{NOPCl}$ requires $342.0815 ; 364.0635$ (40) $\left[\mathrm{M}+\mathrm{Na}^{+}\right] . \mathrm{C}_{19} \mathrm{H}_{17} \mathrm{NOPClNa}$ requires 364.0634. Anal. Calcd for $\mathrm{C}_{19} \mathrm{H}_{17} \mathrm{ClNOP}: \mathrm{C}, 66.77 ; \mathrm{H}, 5.01 ; \mathrm{N}$, 4.10. Found: C, 66.66; H, 4.86; N, 3.50.

\subsubsection{2.((6,6'-((1,4-diazepane-1,4-diyl)bis(methylene))bis(pyridine-6,2-}

diyl))bis(methylene))bis(diphenylphosphine oxide) (2). To a solution of homopiperazine (293 mg, 2.92 $\mathrm{mmol})$ and $\mathrm{NaOH}(468 \mathrm{mg}, 11.7 \mathrm{mmol})$ in a mixture of $\mathrm{CH}_{2} \mathrm{Cl}_{2}(25 \mathrm{~mL})$ and water $(15 \mathrm{~mL})$ was added 1a $(2.00 \mathrm{~g}, 5.85 \mathrm{mmol})$. The mixture was stirred $\left(23{ }^{\circ} \mathrm{C}, 4 \mathrm{~d}\right)$ and then additional $\mathrm{NaOH}(500 \mathrm{mg}, 12.5$ mmol) was added and the mixture stirred $(6 \mathrm{~d})$. The phases were separated and the aqueous layer extracted with $\mathrm{CH}_{2} \mathrm{Cl}_{2}(3 \times 20 \mathrm{~mL})$. The combined organic layer was dried with $\mathrm{MgSO}_{4}$, filtered and the solvent evaporated under reduced pressure. Purification of the residue, performed by column chromatography (silica gel (60 g), eluant $\mathrm{CH}_{2} \mathrm{Cl}_{2} / \mathrm{MeOH}, 90: 10$ to 80:20), afforded 2 as an orange solid. Yield: $1.05 \mathrm{~g}, 51 \% . \mathrm{Mp} 74-76{ }^{\circ} \mathrm{C} .{ }^{31} \mathrm{P}\left\{{ }^{1} \mathrm{H}\right\}$ NMR (121.49 $\left.\mathrm{MHz}, \mathrm{CDCl}_{3}\right): \delta=29.6 .{ }^{1} \mathrm{H}$ NMR $(300 \mathrm{MHz}$, $\left.\mathrm{CDCl}_{3}\right): \delta=7.66-7.60\left(\mathrm{~m}, 8 \mathrm{H}, H_{12}\right), 7.38\left(\mathrm{t}, J_{\mathrm{HH}}=7.8 \mathrm{~Hz}, 2 \mathrm{H}, H_{7}\right), 7.26-7.13\left(\mathrm{~m}, 16 \mathrm{H}, H_{6,8,13,14}\right), 3.81(\mathrm{~d}$, $\left.J_{H P}=14.1 \mathrm{~Hz}, 4 \mathrm{H}, H_{10}\right), 3.53\left(\mathrm{~s}, 4 \mathrm{H}, H_{4}\right), 2.56-2.45\left(\mathrm{~m}, 8 \mathrm{H}, H_{1,2}\right), 1.63-1.56\left(\mathrm{~m}, 2 \mathrm{H}, H_{13}\right) .{ }^{13} \mathrm{C}\left\{{ }^{1} \mathrm{H}\right\}(75.4$ 
$\left.\mathrm{MHz}, \mathrm{CDCl}_{3}\right): \delta=158.3\left(C_{5}\right), 151.1\left(\mathrm{~d}, J_{C P}=6.9 \mathrm{~Hz}, C_{9}\right), 136.2\left(C_{7}\right), 131.9\left(\mathrm{~d}, J_{C P}=99.9 \mathrm{~Hz}, C_{11}\right), 131.2$ $\left(C_{14}\right), 130.6\left(\mathrm{~d}, J_{C P}=9.4 \mathrm{~Hz}, C_{12}\right), 127.9\left(\mathrm{~d}, J_{C P}=11.8 \mathrm{~Hz}, C_{13}\right), 122.7\left(\mathrm{~d}, J_{C P}=1.8 \mathrm{~Hz}, C_{8}\right), 120.7\left(C_{6}\right)$, $63.3\left(C_{4}\right), 54.3\left(C_{1}\right), 53.8\left(C_{2}\right), 40.2\left(\mathrm{~d}, J_{C P}=64.4 \mathrm{~Hz}, C_{10}\right), 26.7\left(C_{3}\right) . \mathrm{IR}\left(\mathrm{KBr}, \mathrm{cm}^{-1}\right): v=3054,2932$, $2813,1589,1573,1483,1454,1436,1394,1341,1267,1192\left(v_{\mathrm{P}=\mathrm{O}}\right), 1120,1069,1027,994,924,832$, 722, 693, 641, 605, 519. HRMS (ESI): $m / z(\%)=711.3015\left[\mathrm{M}+\mathrm{H}^{+}\right](90) \cdot \mathrm{C}_{43} \mathrm{H}_{45} \mathrm{~N}_{4} \mathrm{O}_{2} \mathrm{P}_{2}$ requires 711.3018; $733.2847\left[\mathrm{M}+\mathrm{Na}^{+}\right](100) . \mathrm{C}_{43} \mathrm{H}_{44} \mathrm{~N}_{4} \mathrm{O}_{2} \mathrm{NaP}_{2}$ requires 733.2837. Anal. Calcd for $2 \cdot 2 \mathrm{CH}_{2} \mathrm{Cl}_{2}$, $\mathrm{C}_{45} \mathrm{H}_{48} \mathrm{Cl}_{2} \mathrm{~N}_{4} \mathrm{O}_{2} \mathrm{P}_{2}:$ C, 61.37; H, 5.49; N, 6.36. Found: C, 62.49; H, 5.37; N, 6.27.

2.2.1.3. 2-(chloromethyl)-6-((diphenylphosphoryl)methyl)pyridine 1-oxide (1b). A mixture of $\mathbf{1 a}(2.00 \mathrm{~g}$, $5.85 \mathrm{mmol})$ and $m \mathrm{CPBA}(77 \%, 2.00 \mathrm{~g}, 8.78 \mathrm{mmol})$ in $\mathrm{CH}_{2} \mathrm{Cl}_{2}(50 \mathrm{~mL})$ was stirred $\left(18 \mathrm{~h}, 23{ }^{\circ} \mathrm{C}\right)$, and the resulting mixture was quenched with an aqueous solution of $\mathrm{NaOH}(2 \mathrm{M}, 100 \mathrm{~mL})$. After separation of the phases, the organic layer was washed with aqueous $\mathrm{NaOH}$ solution $(2 \mathrm{M}, 3 \times 80 \mathrm{~mL})$, and the combined organic layers were washed with brine $(100 \mathrm{~mL})$, dried over $\mathrm{MgSO}_{4}$, filtered and evaporated to dryness to give $\mathbf{1 b}$ as a white solid that doesn't require further purification. Yield: $2.00 \mathrm{~g}, 96 \%$; Mp 138$140{ }^{\circ} \mathrm{C} .{ }^{31} \mathrm{P}\left\{{ }^{1} \mathrm{H}\right\}$ NMR $\left(121.5 \mathrm{MHz}, \mathrm{CDCl}_{3}\right): \delta=30.8 .{ }^{1} \mathrm{H}$ NMR $\left(300 \mathrm{MHz}, \mathrm{CDCl}_{3}\right): \delta=7.75-7.87(\mathrm{~m}$, $\left.4 \mathrm{H}, H_{9}\right), 7.62\left(\mathrm{~d}, J_{H H}=7.8 \mathrm{~Hz}, 1 \mathrm{H}, H_{3}\right.$ or $\left.H_{5}\right), 7.36-7.22\left(\mathrm{~m}, 7 \mathrm{H}, H_{3}\right.$ or $H_{5}$ and $\left.H_{10,11}\right), 7.00\left(\mathrm{t}, J_{H H}=7.8\right.$ $\left.\mathrm{Hz}, 1 \mathrm{H}, H_{4}\right), 4.53\left(\mathrm{~s}, 2 \mathrm{H}, H_{7}\right), 4.15\left(\mathrm{~d}, J_{H P}=14.1 \mathrm{~Hz}, 2 \mathrm{H}, H_{1}\right) .{ }^{13} \mathrm{C}\left\{{ }^{1} \mathrm{H}\right\} \mathrm{NMR}\left(75.4 \mathrm{MHz}, \mathrm{CDCl}_{3}\right): \delta=$ $146.5\left(C_{6}\right), 143.9\left(\mathrm{~d}, J_{C P}=6.0 \mathrm{~Hz}, C_{2}\right), 131.8\left(\mathrm{~d}, J_{C P}=2.0 \mathrm{~Hz}, C_{11}\right), 131.7\left(\mathrm{~d}, J_{C P}=101.5 \mathrm{~Hz}, C_{8}\right), 130.5$ $\left(\mathrm{d}, J_{C P}=9.9 \mathrm{~Hz}, C_{9}\right), 128.3\left(\mathrm{~d}, J_{C P}=12.1 \mathrm{~Hz}, C_{10}\right), 126.5\left(\mathrm{~d}, J_{C P}=3.9 \mathrm{~Hz}, C_{3}\right), 124.3\left(C_{4}\right.$ or $\left.C_{5}\right), 123.8\left(C_{4}\right.$ or $\left.C_{5}\right), 40.1\left(C_{7}\right), 31.2\left(\mathrm{~d}, J_{C P}=65.6 \mathrm{~Hz}, C_{l}\right) . \mathrm{IR}\left(\mathrm{KBr}, \mathrm{cm}^{-1}\right): v=2973,1566,1484,1435,1404,1389$, $1292,1252,1236,1219,1193\left(v_{\mathrm{P}=\mathrm{O}}\right), 1165,1118,1104,1070,1026,997,974,949,931,897,852,823$, $785,748,735,719,692,617,590,560,541,510,462,421$. HRMS (ESI): $m / z(\%)=358.0774(20)$ $\left[\mathrm{M}+\mathrm{H}^{+}\right] . \mathrm{C}_{19} \mathrm{H}_{18} \mathrm{ClNO}_{2} \mathrm{P}$ requires 358.0758; $380.0588(42)\left[\mathrm{M}+\mathrm{Na}^{+}\right] . \mathrm{C}_{19} \mathrm{H}_{17} \mathrm{ClNNaO}_{2} \mathrm{P}$ requires 380.0578. 737.1294 (100) $\left[2 \mathrm{M}+\mathrm{Na}^{+}\right] . \mathrm{C}_{38} \mathrm{H}_{34} \mathrm{Cl}_{2} \mathrm{~N}_{2} \mathrm{NaO}_{4} \mathrm{P}_{2}$ requires 737.1263. Anal. Calcd for $\mathrm{C}_{19} \mathrm{H}_{17} \mathrm{ClNO}_{2} \mathrm{P}: \mathrm{C}$, 63.79; H, 4.79; N, 3.92. Found: C, 63.46; H, 4.76; N, 3.34. 


\subsubsection{6,6'-((1,4-diazepane-1,4-diyl)bis(methylene))bis(2-((diphenylphosphoryl)methyl)pyridine 1-oxide)}

(3). In a fashion similar to that described for the synthesis of $\mathbf{2}$, a sample of $\mathbf{1 b}(2.3 \mathrm{~g}, 6.43 \mathrm{mmol})$ was combined with a mixture of homopiperazine (943 mg, $2.93 \mathrm{mmol})$ and $\mathrm{NaOH}(516 \mathrm{mg}, 12.9 \mathrm{mmol})$ and stirred $\left(7 \mathrm{~d}, 23{ }^{\circ} \mathrm{C}\right)$. Compound 3 was obtained as a weakly colored, yellow powder: Yield: $1.41 \mathrm{~g}, 59 \%$. Mp 124-126 ${ }^{\circ} \mathrm{C} .{ }^{31} \mathrm{P}\left\{{ }^{1} \mathrm{H}\right\}$ NMR (121.49 MHz, $\left.\mathrm{CDCl}_{3}\right): \delta=30.9 .{ }^{1} \mathrm{H}$ NMR $\left(300 \mathrm{MHz}, \mathrm{CDCl}_{3}\right): \delta=7.79-$ $7.73\left(\mathrm{~m}, 8 \mathrm{H}, H_{12}\right), 7.57\left(\mathrm{~d}, J_{\mathrm{HH}}=7.8 \mathrm{~Hz}, 2 \mathrm{H}, H_{6}\right.$ or $\left.H_{8}\right), 7.40-7.29\left(\mathrm{~m}, 14 \mathrm{H}, H_{6}\right.$ or $H_{8}$ and $\left.H_{13,14}\right), 7.08(\mathrm{t}$, $\left.J_{\mathrm{HH}}=7.8 \mathrm{~Hz}, 2 \mathrm{H}, H_{7}\right) 4.19\left(\mathrm{~d}, J_{H P}=14.1 \mathrm{~Hz}, 4 \mathrm{H}, H_{10}\right), 3.73\left(\mathrm{~s}, 4 \mathrm{H}, H_{4}\right), 2.70-2.66\left(\mathrm{~m}, 8 \mathrm{H}, H_{1,2}\right), 1.79-$ $1.71\left(\mathrm{~m}, 2 \mathrm{H}, H_{13}\right) .{ }^{13} \mathrm{C}\left\{{ }^{1} \mathrm{H}\right\}\left(75.4 \mathrm{MHz}, \mathrm{CDCl}_{3}\right): \delta=150.3\left(C_{5}\right), 143.8\left(\mathrm{~d}, J_{C P}=6.0 \mathrm{~Hz}, C_{9}\right), 131.9\left(C_{14}\right)$, $131.9\left(\mathrm{~d}, J_{C P}=101.6 \mathrm{~Hz}, C_{11}\right), 130.8\left(\mathrm{~d}, J_{C P}=9.9 \mathrm{~Hz}, C_{12}\right), 128.3\left(\mathrm{~d}, J_{C P}=12.1 \mathrm{~Hz}, C_{13}\right), 124.9\left(C_{7,8}\right)$, $123.0\left(C_{6}\right), 56.7\left(C_{1}\right.$ or $\left.C_{2}\right), 56.3\left(C_{4}\right), 54.9\left(C_{1}\right.$ or $\left.C_{2}\right), 31.8\left(\mathrm{~d}, J_{C P}=66.4 \mathrm{~Hz}, C_{10}\right), 27.8\left(C_{3}\right) . \mathrm{IR}(\mathrm{KBr}$, $\left.\mathrm{cm}^{-1}\right): v=3053,2925,1590,1562,1487,1458,1437,1406,1378,1347,1240,1186\left(v_{\mathrm{P}=\mathrm{O}}\right), 1119,1066$ $1027,996,930,849,821,787,745,720,710,695,597,557,518$. HRMS (ESI): $\mathrm{m} / \mathrm{z}(\%)=743.2913[\mathrm{M}+$ $\mathrm{H}^{+}$] (100). $\mathrm{C}_{43} \mathrm{H}_{45} \mathrm{~N}_{4} \mathrm{O}_{4} \mathrm{P}_{2}$ requires 743.2916. Anal. Calcd for 3· $\mathrm{MeOH}, \mathrm{C}_{44} \mathrm{H}_{48} \mathrm{~N}_{4} \mathrm{O}_{5} \mathrm{P}_{2}: \mathrm{C}, 68.21 ; \mathrm{H}, 6.24$; N, 7.23. Found: C, 69.53; H, 5.97; N, 7.54. Anal. Calcd for $3 \cdot \mathrm{H}_{2} \mathrm{O}, \mathrm{C}_{43} \mathrm{H}_{46} \mathrm{~N}_{4} \mathrm{O}_{5} \mathrm{P}_{2}: \mathrm{C}, 67.88 ; \mathrm{H}, 6.09 ; \mathrm{N}$, 7.36. Found: C, $69.53 ; \mathrm{H}, 5.97 ; \mathrm{N}, 7.54$.

\subsubsection{Coordination complex syntheses}

The coordination complexes of $\mathbf{2}$ and $\mathbf{3}$ with $\mathrm{Cu}(\mathrm{II})$ were obtained by addition of equimolar amounts of copper(II) tetrafluoroborate $(240 \mathrm{mg}, 1 \mathrm{mmol})$ in $\mathrm{MeOH}(10 \mathrm{~mL})$ to samples of the ligands $(1 \mathrm{mmol})$ in $\mathrm{MeOH}(10 \mathrm{~mL})$. The mixtures were stirred $\left(2 \mathrm{~h}, 23{ }^{\circ} \mathrm{C}\right)$, the resulting solutions evaporated to dryness, and the solid residues were vacuum-dried. Single crystals of $[\mathrm{Cu}(2)]\left(\mathrm{BF}_{4}\right)_{2}$ were obtained by slow evaporation of a $\mathrm{MeOH}$ solution $\left(23{ }^{\circ} \mathrm{C}\right)$. IR $\left(\mathrm{KBr}, \mathrm{cm}^{-1}\right): v=1156,1189\left(v_{\mathrm{P}=\mathrm{O}}\right)$. Anal. Calcd for $\mathrm{C}_{43} \mathrm{H}_{44} \mathrm{~B}_{2} \mathrm{CuF}_{8} \mathrm{~N}_{4} \mathrm{O}_{2} \mathrm{P}_{2}:$ C, 54.48, H, 4.68, N, 5.91. Found: C, 54.42, H, 4.47, N, 5.86. Single crystals of $[\mathrm{Cu}(3)]\left(\mathrm{BF}_{4}\right)_{2}$ were isolated by slow evaporation of a $t \mathrm{BuOH} / \mathrm{MeOH} / \mathrm{Et}_{2} \mathrm{O}$ solution $\left(23{ }^{\circ} \mathrm{C}\right)$. IR $\left(\mathrm{KBr}, \mathrm{cm}^{-}\right.$ $\left.{ }^{1}\right): \quad v=1207,1196\left(v_{\mathrm{N}-\mathrm{O}}\right), 1175,1161\left(v_{\mathrm{P}=\mathrm{O}}\right)$. HRMS $(\mathrm{ESI}): m / z(\%)=978.2154\left[\mathrm{M}^{\left.-\mathrm{H}^{-}\right]}(10)\right.$. $\mathrm{C}_{43} \mathrm{H}_{43} \mathrm{~B}_{2} \mathrm{CuF}_{8} \mathrm{~N}_{4} \mathrm{O}_{4} \mathrm{P}_{2}$ requires 978.2130. Anal. Calcd for $\mathrm{C}_{43} \mathrm{H}_{44} \mathrm{~B}_{2} \mathrm{CuF}_{8} \mathrm{~N}_{4} \mathrm{O}_{4} \mathrm{P}_{2}: \mathrm{C}$, 52.70, $\mathrm{H}, 4.53, \mathrm{~N}$, 5.72. Found: $\mathrm{C}, 52.13, \mathrm{H}, 4.40, \mathrm{~N}, 5.46$. Selected lanthanide nitrate complexes $(\mathrm{Ln}=\mathrm{La}$ and $\mathrm{Eu})$ were 
prepared in a similar manner by $1: 1$ combinations of $\mathbf{2}$ and $\mathbf{3}$ with $\mathrm{La}\left(\mathrm{NO}_{3}\right)_{3} \cdot x\left(\mathrm{H}_{2} \mathrm{O}\right)$ and $\mathrm{Eu}\left(\mathrm{NO}_{3}\right)_{3} \cdot \mathrm{xH}_{2} \mathrm{O}$. $\left[\mathrm{La}(2)\left(\mathrm{NO}_{3}\right)_{3}\right]:{ }^{31} \mathrm{P}\left\{{ }^{1} \mathrm{H}\right\}\left(121.49 \mathrm{MHz}, d_{4}-\mathrm{MeOH}\right): \delta$ 35.5, 39.3. IR $\left(\mathrm{KBr}, \mathrm{cm}^{-1}\right): v=1155\left(v_{\mathrm{P}=\mathrm{O}}\right)$; $\left[\mathrm{Eu}(2)\left(\mathrm{NO}_{3}\right)_{3}\right]: \mathrm{IR}\left(\mathrm{KBr}, \mathrm{cm}^{-1}\right): v=1156\left(v_{\mathrm{P}=\mathrm{O}}\right) ;\left[\mathrm{La}(\mathbf{3})\left(\mathrm{NO}_{3}\right)_{3}\right]:{ }^{31} \mathrm{P}\left\{{ }^{1} \mathrm{H}\right\}\left(121.49 \mathrm{MHz}, d_{4}-\mathrm{MeOH}\right) \delta 35.7$, 36.7. IR $\left(\mathrm{KBr}, \mathrm{cm}^{-1}\right): v=1211\left(v_{\mathrm{N}-\mathrm{O}}\right), 1160\left(v_{\mathrm{P}=\mathrm{O}}\right)$. Anal. Calcd for $\mathrm{C}_{43} \mathrm{H}_{44} \mathrm{LaN}_{7} \mathrm{O}_{13} \mathrm{P}_{2}: \mathrm{C} 48.37, \mathrm{H} 4.15, \mathrm{~N}$ 9.18. Found: $\mathrm{C} 46.11, \mathrm{H} 4.10, \mathrm{~N}$ 8.93. $\left[\mathrm{Eu}(3)\left(\mathrm{NO}_{3}\right)_{3}\right]$ : IR $\left(\mathrm{KBr}, \mathrm{cm}^{-1}\right): v=1210\left(v_{\mathrm{N}-\mathrm{O}}\right), 1160\left(v_{\mathrm{P}=\mathrm{O}}\right)$. Attempts to obtain single crystals of lanthanide complexes suitable for crystallographic analysis were unsuccessful.

\subsubsection{Single crystal $X$-ray diffraction analyses}

Single crystals of $\mathbf{1 a},[\mathrm{Cu}(\mathbf{2})]\left(\mathrm{BF}_{4}\right)_{2}$ and $[\mathrm{Cu}(\mathbf{3})]\left(\mathrm{BF}_{4}\right)_{2}$ were obtained as described above and specimens (colorless block, $0.191 \times 0.251 \times 0.348 \mathrm{~mm}$, blue platlet, $0.084 \times 00.246 \times 0.289 \mathrm{~mm}$, and blue rod, $0.137 \times 0.153 \times 0.266 \mathrm{~mm}$, respectively) were coated with Paratone oil and mounted on a MiTeGen support attached to a metallic pin using epoxy. The X-ray diffraction data were collected with a Bruker APEX II CCD system equipped with a graphite monochromator, MoK $\alpha$ sealed X-ray tube $(\lambda=0.71073 \AA)$ and Oxford Cryostream 700 low temperature device. Full spheres of diffraction data were collected, integrated [43] and processed with the Bruker APEX2 software suite [44] including corrections for absorption (SADABS) [45]. The structures were solved by direct methods and refined with full-matrix least-squares on $\mathrm{F}^{2}$ using SHELXTL [46]. Selected crystal data are provided in Table 1. The nonhydrogen atom positions were refined anisotropically, and H-atoms were placed in geometrically calculated positions and refined with $U_{i s o}=1.2 U_{e q}$ of the parent atom. One of the two $\mathrm{BF}_{4}{ }^{-}$anions in $[\mathrm{Cu}(2)]\left(\mathrm{BF}_{4}\right)_{2}$ was found to be disordered over two positions. The occupancies of the disordered atoms were allowed to freely refine, and they converged with relative occupancies of 52/48 for the major and minor positions. The structure for $[\mathrm{Cu}(3)]\left(\mathrm{BF}_{4}\right)_{2}$ was refined as a two-component inversion twin. Disordered diethyl ether lattice solvent molecules could not be appropriately modelled, and they were accounted for by using SQUEEZE $[47,48]$ which found solvent-accessible voids of $484 \AA^{3}$ containing $102 \mathrm{e}^{-}$. Several of the F-atoms in the $\mathrm{BF}_{4}^{-}$anions were modeled over two positions, with the relative occupancies allowed to refine freely and the B-F bond lengths restrained with the SADI command. It is 
noted further that $[\mathrm{Cu}(3)]\left(\mathrm{BF}_{4}\right)_{2}$ crystalizes in the space group $P c$ with a strong Ia super cell. The majority of the atoms and the bulk of the scattering power conform to the Ia cell. The distortions from Ia symmetry result from the fluorine atoms of the $\mathrm{BF}_{4}{ }^{-}$anions and from rotations of the $\mathrm{Ph}$ rings around the $\mathrm{P}-\mathrm{C}$ bonds. The approximately 4000 reflections which violate the $I$ condition are very weak. Including these reflections degrades the quality of the data set so that the standard deviations of bond distances and angles in the $P c$ model are much larger than in the $I a$ model which ignores these weak reflections. The structures of the phenyl rings and $\mathrm{BF}_{4}^{-}$anions are well known, and this structure adds nothing of significance to that data base. For these reasons the structure of this complex is based upon the stronger reflections of the $I a$ super cell. Additionally, the structure of $\left[\mathrm{Cu}(\mathbf{3})^{2+}\right]$ also approximates $I 2 / a$ symmetry, and the Flack parameter of 0.38 indicates either a centro-symmetric structure or a racemic twin. In the $I 2 / a$ model, a two-fold axis passes through the $\mathrm{Cu}$ ion and the midpoint of the N2-N3 line. This two-fold axis rotates the two carbon chain of the piperazine ring onto the three carbon chain thus disordering them. In addition, it makes the $\mathrm{Cu} 1-\mathrm{O} 1$ and $\mathrm{Cu} 1-\mathrm{O} 4$ interactions equivalent. This disorder is absent in the Ia model in which the $\mathrm{Cu} 1-\mathrm{O} 1$ and $\mathrm{Cu} 1-\mathrm{O} 4$ distances are quite different. Unequal interaction of the $\mathrm{Cu}$ ion with the two phosphine oxide donors is further indicated by the IR data which shows two different $\mathrm{P}=\mathrm{O}$ stretching frequencies both shifted from that of the uncoordinated ligand. This provides further support for the choice of the Ia model.

\subsubsection{Molecular Mechanics Calculations}

Geometry optimizations of free ligands and lanthanide-bound structures of 2-5 were accomplished with a MM3 force field [49-51] by using a points-on-a-sphere metal ion [52] as implemented in PCModel software [53]. Conformational searches to locate the most stable form for each structure were performed with the GMMX algorithm provided in this software.

\subsubsection{Distribution Studies.}

Extraction experiments were carried out using 1,2-dichloroethane (OmniSolv, EM Science) as the diluent. The aqueous phases were prepared using nitric acid (J. T. Baker, Ultrex II) and europium nitrate (Aldrich, 99.9\%). Distilled, deionized water was obtained from a Barnstead Nanopure filter system 
(resistivity at least $18.2 \mathrm{M} \Omega-\mathrm{cm}$ ) and used to prepare all the aqueous solutions. The radioisotope ${ }^{241} \mathrm{Am}$ was provided by the Radiochemical and Engineering Research Center (REDC) of ORNL. The radiotracer ${ }^{152 / 154} \mathrm{Eu}$ was obtained from Isotope Products, Burbank, CA. Both were added as spikes to the aqueous phases in the sample equilibration vials in the extraction experiments.

Phases at an 1:1 organic to aqueous (O:A) phase ratio were combined in $2 \mathrm{~mL}$ polypropylene microtubes, which were then capped and mounted by clips on a disk that was rotated in a constant-temperature air box at $25.0 \pm 0.5{ }^{\circ} \mathrm{C}$ for 1 hour. After the contacting period, the tubes were centrifuged for 5 min at $3000 \mathrm{RPM}$ and $25^{\circ} \mathrm{C}$ in a Beckman Coulter ${ }^{\mathrm{TM}}$ Allegra 6R temperature-controlled centrifuge. A $250 \mu \mathrm{L}$ aliquot of each phase was sub-sampled and counted using a Canberra Analyst pure Ge Gamma counter. Counting times were sufficient to ensure that counting error was a small fraction of the precision of the obtained distribution ratios, considered from a combination of volumetric, replicate and counting errors to be $\pm 5 \%$. Americium and europium distribution ratios were calculated as the ratio of the volumetric count rates of the ${ }^{241} \mathrm{Am}$ and ${ }^{152 / 154} \mathrm{Eu}$ isotopes in each phase at equilibrium.

\section{Results and discussion}

\subsection{Ligand syntheses and characterization}

The precursor, 2-(diphenylphosphinoylmethyl)-6-(chloromethyl)pyridine, 1a, for the synthesis of $\mathbf{1 b}$ and 2 was prepared by heating, under nitrogen, ethyl diphenylphosphinite, $\mathrm{Ph}_{2} \mathrm{POEt}$, with a large excess of 2,6-bis(chloromethyl)pyridine in $o$-xylene. The resulting product was purified by column chromatography and isolated in $89 \%$ yield as a white powder that can be stored indefinitely for subsequent substitution reactions. The compound was characterized spectroscopically (FTIR, NMR and HRMS), and its molecular structure was unambiguously confirmed by single crystal X-ray diffraction analysis. A view of the molecule is shown in Figure 2, and selected bond lengths are listed in Table 2.

[Insert Figure 2 near here] 
The target ligands, ((6,6'-((1,4-diazepane-1,4-diyl)bis(methylene))bis(pyridine-6,2diyl))bis(methylene))bis(diphenylphosphine oxide), 2, and 6,6'-((1,4-diazepane-1,4diyl)bis(methylene))bis(2-((diphenylphosphoryl)methyl)pyridine 1-oxide), 3, were prepared in good yields as summarized in Scheme 1. Treatment of homopiperazine, 1,4-diazacycloheptane,DACH, with two equivalents each of 2-(diphenylphosphinoylmethyl)-6-(chloromethyl)pyridine, $\mathbf{1 a}$, and $\mathrm{NaOH}$ in a methylene chloride/water solution, followed by stirring $\left(2 \mathrm{~d}, 23^{\circ} \mathrm{C}\right)$ gave a mixture that indicated only partial alkylation of the amine. Addition of another two equivalents of $\mathrm{NaOH}$ and further stirring $(6 \mathrm{~d}, 23$ ${ }^{\circ} \mathrm{C}$ ) provided good conversion to the bis-alkylation product, 2. Purification of the product by column chromatography led to isolation of $\mathbf{2}$ as an orange solid with $51 \%$ yield. Attempts to obtain the Noxidized derivative, $\mathbf{3}$, by treatment of $\mathbf{2}$ with aqueous hydrogen peroxide solutions or with $m \mathrm{CPBA}$ in methylene chloride led to degradation of the ring system. In contrast, combination of 1a with $m$ CPBA in methylene chloride gave clean, high yield conversion of 1a to 2-(diphenylphosphinoylmethyl)-6(chloromethyl)pyridine N-oxide, $\mathbf{1 b}$. Subsequent combination of two equivalents of $\mathbf{1 b}$ and four equivalents of $\mathrm{NaOH}$ with $\mathrm{DACH}$ in $\mathrm{CH}_{2} \mathrm{Cl}_{2} / \mathrm{H}_{2} \mathrm{O}$, followed by stirring of the mixture for seven days, led to isolation of $\mathbf{3}$ as a pale yellow solid in 59\% yield. Efforts to obtain analytically pure samples of $\mathbf{2}$ and $\mathbf{3}$ by recrystallization from several solvent combinations gave solvated compositions. The best CHN analysis agreements were obtained for compositions corresponding to $2 \cdot 2 \mathrm{CH}_{2} \mathrm{Cl}_{2}$ and $3 \cdot \mathrm{MeOH}$. Both compounds display a solvent-free parent ion $\left[\mathrm{M}+\mathrm{H}^{+}\right]$in high resolution mass spectra, and IR spectra show a strong absorption assigned to a phosphoryl stretching vibration at $1193 \mathrm{~cm}^{-1}$ based upon assignments in spectra for similar compounds [12-25] and for $\mathbf{1 a}, 1200 \mathrm{~cm}^{-1}$. Compound $\mathbf{3}$ also exhibits an infrared band at $1236 \mathrm{~cm}^{-1}$ tentatively assigned to the pyridine $\mathrm{N}$-oxide stretch. The ${ }^{31} \mathrm{P}$ NMR spectra for 2 and 3 contain a single resonance with strong solvent dependence: $\mathbf{2}, \delta 29.6\left(\mathrm{CDCl}_{3}\right)$ and $34.5\left(d_{4^{-}}\right.$ $\mathrm{MeOH}) ; \mathbf{3}, \delta 30.9\left(\mathrm{CDCl}_{3}\right)$ and $31.2\left(d_{4}-\mathrm{MeOH}\right)$. The small downfield shift in $\mathrm{CDCl}_{3}$ solution upon $\mathrm{N}$ oxidation is typical as noted previously $[12,13,22]$. The ${ }^{1} \mathrm{H}$ and ${ }^{13} \mathrm{C}$ NMR spectra (Supplementary data) for the compounds also are assigned and consistent with the proposed structures.

[Insert Scheme 1 near here] 


\subsection{Molecular mechanics calculations}

As noted in the Introduction, one of our current ligand design objectives involves grafting of two or more known $f$-element selective chelating ligand fragments, such as $\mathbf{B}$ and $\mathbf{C}$, to organic platforms in order to obtain a desired pre-organized donor environment. In the current study, three grafted ligands based upon two cyclic diamine platforms were computationally evaluated. The first diamine platform considered was piperazine. It is well known that $N, N^{\prime}$-disubstituted piperazines, in their ground state, typically favor a 1,4-diequatorial chair conformation [30-33,54]. This structure would favor the formation of linear, dinuclear or polymeric coordination complexes over maximal chelating mononuclear complexes. In fact, Hancock and coworkers [55] have used MM calculations to estimate that the boat conformation of the tetraamine 1,4-bis(2-aminoethyl)-1,4-diazacyclohexane lies $7 \mathrm{kcal} / \mathrm{mole}$ higher in energy than the chair conformation. Further, it was experimentally observed that the stabilities of transition metal complexes of this tetraamine are remarkably low [55] consistent with the formation of weak dinuclear complexes instead of chelated mononuclear complexes in solution. Nash and coworkers [56] have also recently reported low stability constants for $\mathrm{Nd}(\mathrm{III})$ and $\mathrm{Am}(\mathrm{III})$ complexes of the tetraamine $N, N^{\prime}$-bis(2-pyridylmethyl)piperazine, and this was attributed to poor donor group preorganization in the chair conformation of this ligand. Nonetheless, a number of mononuclear metal chelating complexes that contain a 1,4-bis(donor decorated) piperazine ligands in a boat conformation have been isolated and structurally characterized including examples with Al(III) [33] and several transition metal ions $[30,31,35,55]$.

As a starting point, in the present study, the steric energetics for the interconversion of the global minimum chair and the boat conformations of the simple model molecule $N, N^{\prime}$-dimethyl piperazine were estimated at the MM3 and MP2/6-31+G*levels of theory and found to be 9.5 and $10.1 \mathrm{kcal} / \mathrm{mole}$, respectively. This result is consistent with estimates reported by Niemeyer [54] and Hancock and coworkers [55] for related $N, N^{\prime}$-disubstitued piperazines. Next, the steric energetics involved in hexadentate binding of the potential ligands, ((6,6'-(piperazine-1,4-diylbis(methylene))bis(pyridine-6,2diyl))bis(methylene))bis(diphenylphosphine oxide), 4, and 6,6'-(piperazine-1,4- 
diylbis(methylene))bis(2-((diphenylphosphoryl)methyl)pyridine 1-oxide), 5, based upon the piperazine scaffold (Figure 3), were examined at the MM3 level of theory. The changes in energy accompanying

[Insert Figure 3 near here]

reorganization of the molecules from their energy minimized free-ligand states, both of which approximate a chair conformation, to energy minimized, boat-shaped, hexadentate, $\mathrm{N}_{\mathrm{am}} \mathrm{N}_{\mathrm{am}} \mathrm{N}_{\text {pyr }} \mathrm{N}_{\text {pyr }} \mathrm{O}_{\mathrm{P}} \mathrm{O}_{\mathrm{P}}$ and $\mathrm{N}_{\mathrm{am}} \mathrm{N}_{\mathrm{am}} \mathrm{O}_{\mathrm{N}} \mathrm{O}_{\mathrm{N}} \mathrm{O}_{\mathrm{P}} \mathrm{O}_{\mathrm{P}}$ coordination complex structures on a medium sized lanthanide cation, i.e., in $\left[\mathrm{Eu}(\mathbf{4})^{3+}\right]$ and $\left[\mathrm{Eu}(\mathbf{5})^{3+}\right]$, were evaluated in the gas phase by use of a force field-based structure scoring approach described previously [57]. The method identifies ligand:metal structures that have low conformational energies, low degrees of induced strain and few restricted bond rotations. In this approach, the calculated relative strain free energy $(\mathrm{G})$ per donor group can be compared for similar ligand types. The method has been successfully employed for a host of other ligand systems [58] including studies of several related NOPO and NOPOPO ligands [23-25,59-63]. In the present case, the calculated $(\mathrm{G})$ and $(\mathrm{G})$ per donor group values are: 4, $22.0 \mathrm{kcal} / \mathrm{mole}$ and $3.67 \mathrm{kcal} / \mathrm{mole} /$ donor group; 5, $24.27 \mathrm{kcal} / \mathrm{mole}$ and $4.05 \mathrm{kcal} / \mathrm{mole} /$ donor group.

Qualitative CPK model building for $\mathbf{2}$ and $\mathbf{3}$ indicated that these molecules, compared to $\mathbf{4}$ and $\mathbf{5}$, might be sterically less constrained against adoption of the boat conformation compatible with hexadentate ligand:metal binding. As expected, the computed energy minimized free ligand structures for $\mathbf{2}$ and $\mathbf{3}$ appear in chair-like conformers as shown in Figures 4a and 5a, respectively, with the ligand donor groups rotated away from each other in order to minimize dipole-dipole repulsions. Therefore,

[Insert Figures 4 and 5 near here]

these ligands, in their respective ground states, are not ideally pre-organized for high denticity chelation. Nonetheless, with addition of Eu(III) to $\mathbf{2}$ and $\mathbf{3}$, boat-shaped hexadentate structures are sterically 
accessible as shown in Figures $4 b$ and $5 b$, and they are adopted with relatively modest calculated steric strain free energies: $\mathbf{2},(\mathrm{G})=16.91 \mathrm{kcal} / \mathrm{mole}$ and $2.82 \mathrm{kcal} / \mathrm{mole} / \mathrm{donor} ; \mathbf{3},(\mathrm{G})=19.24 \mathrm{kcal} / \mathrm{mole}$ and $3.21 \mathrm{kcal} / \mathrm{mole} /$ donor . These values are significantly smaller than those calculated for $\mathbf{4}$ and $\mathbf{5}$, and they indicate that 1,4-diazapane should be a better platform for development of new chelating ligands than piperazine. In response to crystal structure determinations described below, the strain energetics for pentadentate structures formed with a $\mathrm{N}_{\mathrm{am}} \mathrm{N}_{\mathrm{am}} \mathrm{N}_{\text {pyr }} \mathrm{N}_{\text {pyr }} \mathrm{O}_{\mathrm{P}}$ binding mode in $\left[\mathrm{Eu}(2)^{3+}\right]$ (Figure $4 \mathrm{c}$ ) and with a $\mathrm{N}_{\mathrm{am}} \mathrm{N}_{\mathrm{am}} \mathrm{O}_{\mathrm{N}} \mathrm{O}_{\mathrm{N}} \mathrm{O}_{\mathrm{P}}$ binding mode in [ $\mathrm{Eu}(3)^{3+}$ (Figure 5c) were also computed. The steric strain free energies are: $\mathbf{2},(\mathrm{G})=11.86 \mathrm{kcal} / \mathrm{mole}$ and $2.37 \mathrm{kcal} / \mathrm{mole} /$ donor; $\mathbf{3}, 16.68 \mathrm{kcal} / \mathrm{mole}$ and 3.34 $\mathrm{kcal} / \mathrm{mole} /$ donor. Together, these values suggest that steric factors should not seriously retard the formation of structures with either of the high denticity interaction modes of these ligands with a trivalent lanthanide ion, and the stabilities of the complexes should be largely governed by the bond enthalpies of complexation. Of course, additional stability would be realized if more sterically pre-organized ligand structures were realized.

\subsection{Metal ion coordination chemistry}

The initial motive to characterize the coordination chemistry of ligands $\mathbf{2}$ and $\mathbf{3}$, with two tethered NPO or NOPO fragments on the 1,4-diazepane backbone, derived from interest to compare the ligand:metal combining ratios and structures of their lanthanide(III) ion complexes against the known combining ratios and structures displayed by the parent NPO and NOPO ligand types $\mathbf{B}$ and $\mathbf{C}$ reported previously $[12,25]$. With $\mathbf{B}$ - and $\mathbf{C}$-type ligands, coordination complexes with ligand:Ln combining ratios 1-4 have been observed in solution. For the B-type ligand:Ln complexes, it has been assumed that the NPO ligand acts as a bidentate $\mathrm{NO}_{\mathrm{P}}$ chelator, although no examples have so far been unambiguously characterized by single crystal X-ray diffraction techniques. On the other hand, several complexes of the C-type ligands with 1:1, 2:1 and 4:1 combining ratios have been structurally characterized, and in each case the ligand binds in a bidentate $\mathrm{O}_{\mathrm{N}} \mathrm{O}_{\mathrm{P}}$ fashion. In the present study, $1: 1$ combinations of $\mathbf{2}$ and $\mathbf{3}$ with $\mathrm{La}\left(\mathrm{NO}_{3}\right)_{3} \cdot \mathrm{xH}_{2} \mathrm{O}$ and $\mathrm{Eu}\left(\mathrm{NO}_{3}\right)_{3} \cdot \mathrm{xH}_{2} \mathrm{O}$ in $\mathrm{MeOH}$ solution produced complexes that are isolated as fine powders. Elemental analyses $(\mathrm{CHN})$ are most consistent with the expected 1:1 ligand:Ln stoichiometry, 
but partial loss of weakly coordinating lattice solvent molecules from the putative compositions, $\operatorname{Ln}(2)\left(\mathrm{NO}_{3}\right)_{3} \cdot(\text { Solvent })_{\mathrm{x}}$ and $\mathrm{Ln}(\mathbf{3})\left(\mathrm{NO}_{3}\right)_{3} \cdot(\text { Solvent })_{\mathrm{x}}(\mathrm{Ln}=\mathrm{La}, \mathrm{Eu})$, prevented accurate overall composition conclusions. Infrared spectra for the $\mathrm{Ln}(2)\left(\mathrm{NO}_{3}\right)_{3} \cdot(\text { Solvent })_{\mathrm{x}}$ complexes, recorded from $\mathrm{KBr}$ pellets, contain a strong absorption in the region $1158-1155 \mathrm{~cm}^{-1}$. The complete disappearance of the free ligand absorption at $1193 \mathrm{~cm}^{-1}$ and the down-frequency shifts $\left(\Delta v=35-38 \mathrm{~cm}^{-1}\right)$ of this band are consistent with $\mathrm{Ln}$ (III) ion binding of both of the phosphoryl donor groups in the solid state. On the other hand, a ${ }^{31} \mathrm{P}$ NMR spectrum for $\mathrm{La}(2)\left(\mathrm{NO}_{3}\right)_{3}$ in $d_{4}-\mathrm{MeOH}$ shows two equally intense resonances at 35.5 ppm and $39.3 \mathrm{ppm}$. The former is only slightly shifted from the free ligand resonance $\left(34.5 \mathrm{ppm}\right.$ in $d_{4^{-}}$ $\mathrm{MeOH}$ ). This may indicate that one of the phosphoryl groups is not bonded to the $\mathrm{La}(\mathrm{III})$ ion in $\mathrm{MeOH}$ solution. Alternatively, two equal intensity resonances may arise due to the presence of stereoisomers. In a hexadentate ligand structure the complex would be non-centric, the $\mathrm{La}(\mathrm{III})$ would be a stereo-center and the amine N-atoms would be chiral. Similarly, the infrared spectra for the complexes $\operatorname{Ln}(3)\left(\mathrm{NO}_{3}\right)_{3} \cdot(\text { Solvent })_{x}$, recorded from $\mathrm{KBr}$ pellets, display a single, strong absorption in the region 1160$1159 \mathrm{~cm}^{-1}\left(\Delta v=33-34 \mathrm{~cm}^{-1}\right)$ consistent with coordination of both phosphoryl groups. In addition, there is a medium intensity band at $1211-1210 \mathrm{~cm}^{-1}$ that is assigned to coordinated pyridine $\mathrm{N}$-oxide functional groups $\left(\Delta v=25-26 \mathrm{~cm}^{-1}\right)$. The ${ }^{31} \mathrm{P}$ NMR spectrum for $\mathrm{La}(3)\left(\mathrm{NO}_{3}\right)_{3}$ in $d_{4}-\mathrm{MeOH}$ also shows two equal intensity resonances at 35.7 and $36.7 \mathrm{ppm}$, both shifted downfield from the free ligand resonance (33.4 ppm in $d_{4}-\mathrm{MeOH}$ ). These spectroscopic data suggest that, at the least, both NOPO fragments in $\mathbf{3}$ are coordinated in a bidentate, $\mathrm{O}_{\mathrm{N}} \mathrm{O}_{\mathrm{P}}$, mode to the $\mathrm{Ln}(\mathrm{III})$ ions. Unfortunately, the data do not unambiguously identify the coordination involvement of the two amine nitrogen donor centers, but the appearance of two equal intensity ${ }^{31} \mathrm{P}$ resonances, as mentioned above, suggests the formation of stereoisomers of a hexadentate complex. Unfortunately, attempts to obtain single crystals for X-ray diffraction analysis from several solvents and solvent combinations have so far been unsuccessful; therefore, the detailed structural assignment of tetradentate, pentadentate or hexadentate ligand binding by $\mathbf{2}$ and $\mathbf{3}$ on Ln(III) ions remains uncertain. 
In support of other research interests, the coordination chemistry of $\mathbf{2}$ and $\mathbf{3}$ with several transition metal cations [ $\mathrm{Fe}(\mathrm{III}), \mathrm{Mn}(\mathrm{II}), \mathrm{Ni}(\mathrm{II})$ and $\mathrm{Cu}(\mathrm{II})]$ was also explored. The results for $\mathrm{Cu}(\mathrm{II})$ are pertinent to the observations made for the lanthanide complexes, and the details are described here. The 1:1 combinations of $\mathbf{2}$ and $\mathbf{3}$ with $\mathrm{Cu}\left(\mathrm{BF}_{4}\right)_{2}$ in $\mathrm{MeOH}$ result in the formation of blue, solvent-free complexes, $[\mathrm{Cu}(2)]\left(\mathrm{BF}_{4}\right)_{2}$ and $[\mathrm{Cu}(3)]\left(\mathrm{BF}_{4}\right)_{2}$, and $\mathrm{CHN}$ analyses are in good agreement with these compositions. Furthermore, a high resolution mass spectrum (ESI negative ion mode) for $[\mathrm{Cu}(3)]\left(\mathrm{BF}_{4}\right)_{2}$ displays a parent ion consistent with the proposed composition. The infrared spectrum $(\mathrm{KBr})$ for $[\mathrm{Cu}(2)]\left(\mathrm{BF}_{4}\right)_{2}$ shows two absorptions in the phosphoryl stretch region $\left(1189\right.$ and $\left.1156 \mathrm{~cm}^{-1}\right)$. These values, compared to the value for the free ligand phosphoryl stretch $\left(v_{\mathrm{PO}}=1193 \mathrm{~cm}^{-1}\right)$, suggest that one of the two phosphoryl groups in the ligand does not interact appreciably with the $\mathrm{Cu}$ (II) ion. On the other hand, the IR spectrum for $[\mathrm{Cu}(3)]\left(\mathrm{BF}_{4}\right)_{2}$ displays a shoulder $\left(1207 \mathrm{~cm}^{-1}\right)$ on a strong absorption $\left(1196 \mathrm{~cm}^{-1}\right)$ both shifted from the tentatively assigned pyridine $\mathrm{N}$-oxide vibration in the free ligand $\left(1236 \mathrm{~cm}^{-1}\right)$ and two strong absorptions (1175 and $\left.1161 \mathrm{~cm}^{-1}\right)$ both shifted from the phosphoryl stretch of the free ligand $\left(1193 \mathrm{~cm}^{-1}\right)$. Although there is some uncertainty involved with the assignment of these infrared bands, the data appear to support a conclusion that ligand 3 binds with $\mathrm{Cu}(\mathrm{II})$ through both NOPO fragments, perhaps inequivalently, as bidentate chelating ligands.

\subsection{Single crystal X-ray diffraction analyses for copper(II) complexes}

Unfortunately, suitable single crystals for lanthanide complexes containing ligands $\mathbf{2}$ and $\mathbf{3}$ were not obtained; however, crystals of $[\mathrm{Cu}(\mathbf{2})]\left(\mathrm{BF}_{4}\right)_{2}$ and $[\mathrm{Cu}(\mathbf{3})]\left(\mathrm{BF}_{4}\right)_{2}$ were formed, and $\mathrm{X}$-ray crystal structure determinations were completed. Views of the $\mathrm{Cu}(\mathrm{L})^{2+}$ cations are shown in Figures 6 and 7, and key bond lengths are summarized in Table 2. The structure determinations for both complexes confirm the 1:1 ligand: $\mathrm{Cu}$ stoichiometry. It is noted that the amino nitrogen centers in both complexes are bonded to four different substituents, and they are, therefore, chiral. While the ligands and their complexes must be racemic, the space groups of the crystals, $P 2$ and $I a$, are non-centric. Therefore, the complexes have spontaneously resolved upon crystallization. The crystal of $[\mathrm{Cu}(3)]\left(\mathrm{BF}_{4}\right)_{2}$ is a racemic twin in the ratio $62 / 38(2)$ while the Flack parameter for $[\mathrm{Cu}(2)]\left(\mathrm{BF}_{4}\right)_{2}, 0.019(13)$ indicates no detectable racemate. 
In the $\mathrm{Cu}(2)^{2+}$ cation, the potentially hexadentate ligand is clearly bonded to the $\mathrm{Cu}(\mathrm{II})$ center in a pentadentate fashion by using the two amine $\mathrm{N}$-atoms (N2 and N3), the two pyridine $\mathrm{N}$-atoms (N1 and N4) and one of the two phosphine oxide $\mathrm{O}$-atoms, $\mathrm{O}$ (1). The bonding $\mathrm{Cu}-\mathrm{O}_{\mathrm{P}}$ bond length, $\mathrm{Cu} 1-\mathrm{O} 1$, 2.105(4) $\AA$, is comparable with the mean distance, $2.078 \AA$ (range: $1.9-2.547 \AA$ ) calculated from 93 structures for copper:organophosphine oxide complexes reported in the Cambridge Database [64]. The second phosphine oxide $\mathrm{O}$-atom is considered to be nonbonding with a separation of $\mathrm{Cu} 1 \cdots \mathrm{O} 2,3.288(5)$ $\AA$. The neutral donor atoms generate a distorted square-pyramidal geometry at the $\mathrm{Cu}(\mathrm{II})$ ion in which the four $\mathrm{N}$-atoms are considered to occupy the square plane positions. The plane is significantly ruffled as indicated by calculated atom deviations from the best plane: N1, 0.318(3) $\AA$; N2, -0.438(4) $\AA$; N3, $0.430(3) \AA$ and $\mathrm{N} 4,-0.310(3) \AA$. The $\mathrm{Cu}(\mathrm{II})$ center is $0.367(3) \AA$ above the plane displaced toward the apical phosphoryl O1-atom. This structure is related to the structure reported for the complex $\left[\mathrm{Cu}(4)\left(\mathrm{OClO}_{3}\right)\right]\left(\mathrm{ClO}_{4}\right)$, wherein the neutral ligand 4, 1,4-bis(pyridine-2-ylmethyl)-1,4-diazepane, is identical to 2 absent the two appended 2-methylphosphine oxide arms on the pyridine rings [31]. In this case, $\mathbf{4}$ coordinates as a tetradentate ligand by employing the two amine $\mathrm{N}$-atoms and the two pyridine $\mathrm{N}$ atoms. The fifth (axial) coordination position is occupied by an O-atom from an inner-sphere perchlorate ion. The $\mathrm{Cu}-\mathrm{N}$ bond lengths in the $\left[\mathrm{Cu}(4)^{2+}\right]$ cation: $\mathrm{Cu}-\mathrm{N}_{\text {amine }}, 2.006(4)$ and 2.003(4) $\AA$; $\mathrm{Cu}-\mathrm{N}_{\mathrm{pyr}}$, $1.966(3)$ and 2.002(4) $\AA$, are more similar to each other than the related bond lengths in $\left[\mathrm{Cu}(\mathbf{2})^{2+}\right]: \mathrm{Cu}$ $\mathrm{N}_{\text {amine }}, 2.004(5)$ and 1.990(6) $\AA$; Cu- $\mathrm{N}_{\text {pyr }}, 1.980(5)$ and 2.123(6) $\AA$. The axial O-atom bond length, 2.328(4) $\AA$, in the $\left[\mathrm{Cu}(4)^{2+}\right]$ complex is much longer than the $\mathrm{Cu}-\mathrm{O}_{\mathrm{P}}$ bond length in $\left[\mathrm{Cu}(\mathbf{2})^{2+}\right]$, and the short distance, 2.105(4) $\AA$, in the latter contributes to the greater distortion of the square-pyramidal geometry of this complex. The significant difference in P-O bond lengths, P1-O1, 1.508(4) $\AA$, and P2-O2, 1.484(5) $\AA$, is consistent with the assignment of the former to the $\mathrm{Cu}(\mathrm{II})$-bound phosphine oxide group and the latter to the non-bonded phosphine oxide group.

[Insert Figure 6 near here] 
For $\left[\mathrm{Cu}(3)^{2+}\right]$, the potentially hexadentate ligand generates an inner coordination sphere that, based upon internal bond angles at the $\mathrm{Cu}(\mathrm{II})$, most closely corresponds to a distorted octahedron. Two coordination positions are occupied by the diazepane ring amine $\mathrm{N}$-atoms with $\mathrm{Cu} 1-\mathrm{N} 2,2.032(6)$, and Cu1-N3, 1.989(7) $\AA$. The difference in bond lengths, $0.043 \AA$, is much greater than that observed in $\left[\mathrm{Cu}(2)^{2+}\right], 0.014 \AA$, and this may indicate some strain may be incurred in a symmetric hexadentate ligand structure. Two additional coordination positions are occupied by pyridine $\mathrm{N}$-oxide $\mathrm{O}$-atoms with, $\mathrm{Cu} 1$ O2, 1.972(5) $\AA$ and Cu1-O3, 1.924(5) $\AA$, and this difference may also be a response to strain in a fully symmetric, hexadentate binding geometry. A fifth coordination position is occupied by a phosphine oxide O-atom O1 with Cu1-O1, 2.288(4) A. This bond length is significantly longer than the bond length in $\left[\mathrm{Cu}(2)^{2+}\right], 2.105(4) \AA$, and the mean $\mathrm{Cu}-\mathrm{O}_{\mathrm{P}}$ bond length, $2.078 \AA$, in copper:organophosphine oxide complexes, but it falls well within the range of bond lengths mentioned above. The sixth position is considered to be occupied by the O-atom from the second of the two phosphine oxide groups with $\mathrm{Cu} 1 \cdots \mathrm{O} 4,2.701(5) \AA$. This distance is long, and it falls outside of the reported range of bonding distances in copper: organophosphine oxide complexes. However, it does fall within a range, 1.808-2.797 $\AA$, found in copper:organophosphate complexes $[64,65]$. Surprisingly, the two $\mathrm{P}=\mathrm{O}$ bond lengths are identical, and they fall between the bonded and non-bonded $\mathrm{P}=\mathrm{O}$ distances in $\left[\mathrm{Cu}(\mathbf{2})^{2+}\right]$. Taken together, the IR and crystallographic data suggest that both NOPO fragments in ligand $\mathbf{3}$ are bonded in a bidentate mode, but in one of these fragments the coordination is quite asymmetric, and the phosphine oxide interactions with $\mathrm{Cu}(\mathrm{II})$ are of unequal strength.

[Insert Figure 7 near here]

\subsection{Survey Am/Eu extraction analysis}


Previous survey studies of the solvent extraction performance by bifunctional $\mathbf{C}$-type NOPO ligands with $\mathrm{R}=$ 2-ethylhexyl in toluene solution [28] and with $\mathrm{R}=$ phenyl in 1,2-dichloroethane (DCE) solution [62] for $\mathrm{Am}(\mathrm{III})$ and $\mathrm{Eu}(\mathrm{III})$ in nitric acid solutions revealed that these ligands are modest extractants and better than the monofunctional extractant $\mathrm{Ph}_{3} \mathrm{PO}$. Of the two, the latter ligand $(\mathrm{R}=\mathrm{Ph})$ in $\mathrm{DCE}$ gave better performance in the acid range 0.01-3 $\mathrm{M} \mathrm{HNO}_{3}$, and the ligand dependency indicated the formation of at least 2:1 ligand:metal complexes. In order to possibly enhance the extraction performance, various C-type ligand modifications have been previously examined. For example, additional pyridine $\mathrm{N}$-oxide fragments have been added on the 2-methyl carbon atom of the $\mathbf{C}$-type framework; however, these modifications do not lead to improved solvent extraction performance [60]. In the present study, two NOPO fragments have been grafted together on a single 1,4-diazepane platform that might produce a partly pre-organized, high denticity chelate structure comparable with that for $\left[\operatorname{Ln}(\mathbf{C})_{2}{ }^{3+}\right]$ complexes. This should result in enhanced extraction performance for $\mathbf{3}$ compared to $\mathbf{C}$.

The variations in distribution ratios, $\mathrm{D}=\left[\mathrm{M}_{\mathrm{org}}\right] /\left[\mathrm{M}_{\mathrm{aq}}\right]$, for $\mathrm{Am}(\mathrm{III})$ and $\mathrm{Eu}(\mathrm{III})$ in nitric acid solutions (0.01-3 M) exposed to solutions of ligand $\mathbf{3}(0.01 \mathrm{M})$ in DCE $\left(25^{\circ} \mathrm{C}\right)$ are summarized in Figure 8 along with data, recorded under identical conditions, for the bifunctional NOPO ligand, $\mathbf{C}(\mathrm{R}=\mathrm{Ph})$ designated as DPhNOPO. In general, with the exception of the D values for $\mathbf{3}$ at the lowest initial acid

[Insert Figure 8 near here]

concentration, $0.01 \mathrm{M}$, the $\mathrm{D}$ values for both extractants steadily increase as the nitric acid concentration increases up to at least $0.3 \mathrm{M} \mathrm{HNO}_{3}$. The anomalously high $\mathrm{D}$ values for $\mathbf{3}(\mathrm{D}=\sim 0.1)$ at the lowest initial nitric acid concentration $(0.01 \mathrm{M})$ may result from the presence of a very small amount of an acidic, organophilic impurity in the DCE solutions of $\mathbf{3}$ that could act as an effective cation exchanger at the lowest acid concentration. However, no impurities, at a level $>0.1 \%$, in bulk samples of $\mathbf{3}$, such as $\mathrm{Ph}_{2} \mathrm{P}(\mathrm{O}) \mathrm{OH}\left({ }^{31} \mathrm{P} \mathrm{NMR}, \delta 25.8\right)$, were detected by ${ }^{31} \mathrm{P}$ NMR. 
As indicated in Figure 8, in the low nitric acid concentration range, the parent DPhNOPO ligand acts as the stronger extractant compared to 3 . However, it appears that acid/metal cation competition is more prevalent for DPhNOPO at higher acid concentrations $(>0.3 \mathrm{M})$ as its D values dramatically decrease with increasing acid concentration. In comparison, extraction by ligand $\mathbf{3}$ is less impacted by protonation at high acid. At acid concentrations above $1 \mathrm{M}, \mathbf{3}$ is clearly the stronger extractant, and its D values remain high until above $3 \mathrm{M}$ nitric acid concentration. In neither case do these ligands in DCE demonstrate significant Am/Eu separation factors.

\section{Conclusions}

Efficient syntheses for ligands $\mathbf{2}$ and $\mathbf{3}$, each with two appended NPO or NOPO fragments, respectively, on a diazepane backbone, have been developed, and a survey of coordination chemistry with $\mathrm{Ln}\left(\mathrm{NO}_{3}\right)_{3}$ salts completed which indicates that 1:1 complexes readily form. Molecular modeling for the ligands bound to $\mathrm{Eu}(\mathrm{III})$ suggests that both should be able to adopt hexadentate $\mathrm{N}_{\mathrm{am}} \mathrm{N}_{\mathrm{am}} \mathrm{N}_{\text {pyr }} \mathrm{N}_{\text {pyr }} \mathrm{O}_{\mathrm{P}} \mathrm{O}_{\mathrm{P}}$ or hexadentate $\mathrm{N}_{\mathrm{am}} \mathrm{N}_{\mathrm{am}} \mathrm{O}_{\mathrm{N}} \mathrm{O}_{\mathrm{N}} \mathrm{O}_{\mathrm{P}} \mathrm{O}_{\mathrm{P}}$, coordination modes with modest steric strain. Infrared coordination shifts for solid, 1:1 Ln(III) complexes are consistent with hexadentate ligand coordination. Solution ${ }^{31} \mathrm{P}$ NMR data for La(III) complexes show two equal intensity resonances that can result either from a complex with inequivalent phosphine oxide donor sites, e.g., in a pentacoordinate $\mathrm{N}_{\mathrm{am}} \mathrm{N}_{\mathrm{am}} \mathrm{N}_{\text {pyr }} \mathrm{N}_{\mathrm{pyr}} \mathrm{O}_{\mathrm{P}}$ ligand coordination mode, or from the presence of stereoisomers. Unfortunately, single crystals for $\mathrm{Ln}$ (III) complexes were not obtained, and the detailed nature of the ligand coordination on Ln(III) ions remains unclear. On the other hand, complexes with $\mathrm{Cu}(\mathrm{II})$ were also isolated, and crystal structure determinations for 1:1 complexes indicate that, under the conditions employed, at the least pentadentate ligand binding is achieved. In the case of $\left[\mathrm{Cu}(3)^{2+}\right]$, a sixth coordination position is weakly occupied. Survey solvent extraction analyses for 3 in DCE toward Eu(III) and Am(III) in nitric acid solutions indicate that this partially pre-organized ligand, at low aqueous acid concentrations, displays smaller distribution ratios than the parent NOPO ligand; however, at the highest acid concentrations, the distribution ratios are improved relative to the parent NOPO ligand. These results encourage additional, 
more detailed extraction analyses with a more organophilic analog of $\mathbf{3}$ in a more process-friendly solvent such as dodecane. In addition, further efforts to develop structurally improved pre-organized NPO and NOPO extractants on related diazacyclo-alkane platforms are in progress, and additional advances will be described in forthcoming contributions.

\section{Acknowledgements}

This material is based upon work supported by the U.S. Department of Energy (DoE), Office of Science, Office of Basic Energy Sciences, Chemical Sciences, Geosciences and Biosciences Office, under Award Number DE-FG02-03ER15419) (RTP). In addition, funds from the National Science Foundation assisted the purchase of the X-ray diffractometer (CHE-0443580) and NMR spectrometers (CHE-0840523 and 0946690). The authors wish to acknowledge assistance provided by Dr. Jeremy Dehaudt for recording the NMR spectra for 3 in $d_{4}-\mathrm{MeOH}$ and by Dr. Milan Gembicky (Bruker AXS, Inc.) for assistance in the solution of the crystal structure for $[\mathrm{Cu}(3)]\left(\mathrm{BF}_{4}\right)_{2}$.

\section{Appendix A. Supplementary material}

CCDC 1045029-1045031 contain the supplementary crystallographic data for $\mathbf{1 a},[\mathrm{Cu}(\mathbf{2})]\left(\mathrm{BF}_{4}\right)_{2}$ and $[\mathrm{Cu}(3)]\left(\mathrm{BF}_{4}\right)_{2}$. These data can be obtained free of charge via http://www.ccdc.cam.ac.uk/conts/retrieving.html or from the Cambridge Crystallographic Data Centre, 12 Union Road, Cambridge CB2 1EZ, UK; fax: (+44) 1223-336-033; or email: deposit@ccdc.cam.ac.uk. Supplementary spectroscopic data associated with this article can be found in the online version at http:// $\operatorname{xxxxxxx}$

\section{References}

[1] K.L. Nash, C. Madic, J.N. Mathur, J. Lacquement in: L.R. Morss, N.M. Edelstein, J. Fuger (Eds.), The Chemistry of the Actinide and Transactinide Elements, Springer, Dordrecht, The Netherlands, 2006, Vol 4, p 2622 (Chapter 24).

[2] C. Hill in: B.A. Moyer(Ed.) Ion Exchange and Solvent Extraction: A Series of Advances, CRC, Boca Raton, FL, 2010, Vol. 19, 119.

[3] Z. Kolarik, Chem. Rev. 108 (2008) 4208. 
[4] C. Madic, M. Lecomte, P. Baron, B. Baullis, C. R. Phys. 3 (2002) 797.

[5] H.H. Dam, D.N. Reinhoudt, W. Verboom, Chem. Soc. Rev. 36 (2007) 367 and references therein.

[6] S.A. Ansari, P. Pathak, P.K. Mohapatra, V.K. Mauchand, Chem. Rev. 112 (2012) 1751.

[7] S.A. Ansari, P. Pathak, P.K. Mohapatra, V.K. Mauchand, Sep. Purif. Rev. 40 (2011) 43.

[8] A.B. Patil, P. Pathak, V.S. Shinde, S.V. Godbole, P.K. Mohapatra, Dalton Trans. 42 (2013) 1519.

[9] F.W. Lewis, M.J. Hudson, L.M. Harwood, Synlett (2011) 2609 and references therein.

[10] C. Liao, S. Wu, F. Cheng, S. Wang, Y. Liu, B. Zhang, C. Yan, J. Rare Earths 31 (2013) 331.

[11] G.A. Green, “The Defense Implications of Rare Earth Shortages” NCPA Rept. Brief 112, Sept. 2012.

[12] B.M. Rapko, E.N. Duesler, P.H. Smith, R.T. Paine, R.R. Ryan, Inorg. Chem. 32 (1993) 2164.

[13] U. Engelhardt, B.M. Rapko, E.N. Duesler, D. Frutos, R.T. Paine, Polyhedron 14 (1995) 2361.

[14] E.M. Bond, X. Gan, J.R. FitzPatrick, R.T. Paine, J. Alloys Compds. 271-273 (1998) 172.

[15] E.M. Bond, E.N. Duesler, R.T. Paine, M.P. Neu, J.H. Matonic, B.L. Scott, Inorg. Chem. 39 (2000) 4152.

[16] E.M. Bond, E.N. Duesler, R.T. Paine, H. Nöth, Polyhedron 19 (2000) 2135.

[17] X.-M. Gan, S. Parveen, W.L. Smith, E.N. Duesler, R.T. Paine, Inorg. Chem. 39 (2000) 4591.

[18] J.H. Matonic, M.P. Neu, A.E. Enriquez, R.T. Paine, B.L. Scott, J. Chem. Soc., Dalton Trans. (2002) 2328.

[19] X.-M. Gan, E.M. Duesler, R.T. Paine, Inorg. Chem. 40 (2001) 4420.

[20] J.H. Matonic, A.E. Enriquez, B.L. Scott, R.T. Paine, M.P. Neu, Nucl. Sci. Tech. 3 (2002) 100.

[21] R.T. Paine, E.M. Bond, S. Parveen, N. Donhart, E.N. Duesler, K.A. Smith, H. Nöth, Inorg. Chem. 41 (2002) 444 .

[22] X.-M. Gan, R.T. Paine, E.N. Duesler, H. Nöth, Dalton Trans. (2003) 153.

[23] X.-M. Gan, B.M. Rapko, E.N. Duesler, I. Binyamin, R.T. Paine, B.P. Hay, Polyhedron 24 (2005) 469.

[24] S. Pailloux, C.E. Shirima, A.D. Ray, E.N. Duesler, R.T. Paine, J.R. Klaehn, M.E. McIlwain, B.P. Hay, Inorg. Chem. 48 (2009) 3104. 
[25] S. Pailloux, C.E. Shirima, A.D. Ray, E.N. Duesler, K.A. Smith, R.T. Paine, J.R. Klaehn, M.E. McIlwain, B.P. Hay, Dalton Trans. (2009) 7486.

[26] E.M. Bond, U. Engelhardt, T.P. Deere, B.M. Rapko, R.T. Paine, Solvent Extr. Ion Exch. 15 (1997) 381.

[27] E.M. Bond, U. Engelhardt, T.P. Deere, B M. Rapko, R.T. Paine, Solvent Extr. Ion Exch. 16 (1998) 967.

[28] K.L. Nash, C. Lavallette, M. Borkowski, R.T. Paine, X.-M. Gan, Inorg. Chem. 41 (2002) 5849.

[29] J. Sulakova, R. T. Paine, M. Chakravarty, K.L. Nash, Sep. Sci. Tech. 47 (2012) 2015.

[30] J. Ratilainen, K. Airola, R. Fröhlich, M. Nieger, K. Rissanen, Polyhedron 18 (1999) 2265 and references therein.

[31] J.A. Halfen, J.M. Uhan, D.C. Fox, M.P. Mehn, L. Que, Jr., Inorg. Chem. 39 (2000) 4913.

[32] R. Mayilmurugan, H. Stoeckli-Evans, M. Palaniandavar, Inorg. Chem. 47 (2008) 6645.

[33] N.C. Johnstone, E.S. Aazam, P.B. Hitchcock, J.R. Fulton, J. Organomet. Chem. 695 (2010) 170.

[34] S.S. Massoud, R.S. Perkins, K.D. Knierim, S.P. Comiskey, K.H. Otero, C.L. Michel, W.N. Juneau, J.H. Albering, F.A. Mautner, W. Xu, Inorg. Chim. Acta 399 (2013) 177.

[35] F.A. Mautner, J.B. Soileau, P.K. Bankole, A.A. Gallo, S.S. Massoud, J. Mol. Structure 889 (2008) 271.

[36] M. Schmidt, D. Wiedemann, B. Moubaraki, N.F. Chilton, K.S. Murray, K.R. Vignesh, G.

Rajaraman, A. Grohmann, Eur. J. Inorg. Chem. (2013) 958.

[37] N. Saravanan, M. Palaniandavar, Inorg. Chim. Acta 385 (2012) 100.

[38] Y.-M. Guo, M. Du, X. H. Bu, Inorg. Chim Acta 358 (2005) 1887 and references therein.

[39] S. Aime, L. Calabi, C. Cavallotti, E. Gianolio, G.B. Giovenzana, P. Losi, A. Maiocchi, G. Palmisano, M. Sisti, Inorg. Chem. 43 (2004) 7588.

[40] E.M. Elemento, D. Parker, S. Aime, E. Gianoliob, L. Lattuadac, Org. Biomol. Chem. 7 (2009) 1120.

[41] D. Imperio, G.B. Giovenzana, G.L. Law, D. Parker, J.W. Waltona, Dalton Trans. 39 (2010) 9897. 
[42] R. Artali, G. Bombieri, G.B. Giovenzana, M. Galli, L. Lattuada, F. Meneghetti, Inorg. Chim. Acta 407 (2013) 306.

[43] SAINT + 7.01, (2003) Bruker AXS, Inc., Madison, WI 53719.

[44] APEX 2, (2007); Bruker AXS, Inc.: Madison, WI,53719.

[45] G.M. Sheldrick, SADABS 2.10, (2003), University of Gottingen: Gottingen, Germany.

[46] SHELXL-97, (2008), Bruker AXS, Inc.: Madison, WI 53719.

[47] P. van der Sluis, A.L. Spek, Acta Crystallogr. A46 (1990) 194.

[48] A.L. Spek, Acta Crystallogr. A46 (1990) C34.

[49] N.L. Allinger, Y.-H. Yuh, J.-H. Lii, J. Am. Chem. Soc. 111 (1989) 8551.

[50] J.-H. Lii, N.L. Allinger, J. Am. Chem. Soc. 111 (1989) 8566.

[51] J.-H. Lii, N.L. Allinger, J. Am. Chem. Soc. 111, (1989) 8576.

[52] B.P. Hay, Coord. Chem. Rev. 126 (1993) 177.

[53] PCModel, version 9.3, Serena Software, Bloomington, IN.

[54] H.M. Niemeyer, J. Mol. Struct. 57 (1979) 241.

[55] R.D. Hancock, M.P. Ngwenya, A. Evers, P.W. Wade, J.C.A. Boeyens, S.M. Dobson, Inorg. Chem. 29 (1990), 264.

[56] M.D.Ogden, S.I. Sinkov, G.P. Meier, G.J. Lumetta, K.L. Nash, J. Sol. Chem. 41 (2012) 2138.

[57] B.P. Hay, A.A. Oliferenko, J. Uddin, C. Zhang, T.K. Firman, J. Am. Chem. Soc. 127 (2005) 17043.

[58] N.J. Young, B. P. Hay, Chem Commun. 49 (2013) 1354 and references therein.

[59] D. Rosario-Amorin, E.N. Duesler, R.T. Paine, B.P. Hay, L.H. Delmau, S.D. Reilly, A.J. Gaunt, B.L. Scott, Inorg. Chem. 51 (2012) 6667.

[60] S.L. Pailloux, D. Rosario-Amorin, M. Chakravarty, J.-M. Camus, K.A. Smith, E.N. Duesler, D.A. Dickie, R.T. Paine, K.K. Klausmeyer, D.A. Padron, B.P. Hay, L.H. Delmau, Z. Anorg. Allg. Chem. 639 (2013) 1101. 
[61] D. Rosario-Amorin, S. Ouizem, D.A. Dickie, Y. Wen, R. T. Paine, J. Gao, J. K. Grey, A, de Bettencourt Dias, B. P. Hay, L.H. Delmau, Inorg. Chem. 52 (2013) 3063. 
Table 1. Crystallographic Data for $\mathbf{1 a},[\mathrm{Cu}(\mathbf{2})]\left(\mathrm{BF}_{4}\right)_{2}$ and $[\mathrm{Cu}(\mathbf{3})]\left(\mathrm{BF}_{4}\right)_{2}$

\begin{tabular}{|c|c|c|c|}
\hline & $1 \mathbf{a}$ & {$[\mathrm{Cu}(\mathbf{2})]\left(\mathrm{BF}_{4}\right)_{2}$} & {$[\mathrm{Cu}(\mathbf{3})]\left(\mathrm{BF}_{4}\right)_{2}$} \\
\hline Empirical formula & $\mathrm{C}_{19} \mathrm{H}_{17} \mathrm{ClNOP}$ & $\mathrm{C}_{43} \mathrm{H}_{44} \mathrm{~B}_{2} \mathrm{CuF}_{8} \mathrm{~N}_{4} \mathrm{O}_{2} \mathrm{P}_{2}$ & $\mathrm{C}_{43} \mathrm{H}_{44} \mathrm{~B}_{2} \mathrm{CuF}_{8} \mathrm{~N}_{4} \mathrm{O}_{4} \mathrm{P}_{2}$ \\
\hline Crystal size (mm) & $\begin{array}{c}0.191 \times 0.251 \times \\
0.348\end{array}$ & $0.084 \times 0.246 \times 0.289$ & $0.140 \times 0.170 \times 0.279$ \\
\hline Formula weight & 341.77 & 947.94 & 979.92 \\
\hline Crystal system & triclinic & monoclinic & monoclinic \\
\hline Space group & $P-1$ & $P 2_{1}$ & $I a$ \\
\hline Unit cell dimensions & & & \\
\hline$a(\AA)$ & $8.1110(4)$ & $10.8109(6)$ & $14.3839(6)$ \\
\hline$b(\AA)$ & $8.5777(3)$ & $11.7429(6)$ & $17.2343(7)$ \\
\hline$c(\AA)$ & $12.2437(6)$ & $17.1084(10)$ & $18.6996(8)$ \\
\hline$\alpha\left(^{\circ}\right)$ & $80.667(2)$ & 90 & 90 \\
\hline$\beta\left(^{\circ}\right)$ & $78.769(3)$ & $107.119(3)$ & $90.005(2)$ \\
\hline$\gamma\left({ }^{\circ}\right)$ & $84.168(2)$ & 90 & 90 \\
\hline $\mathrm{V}\left(\AA^{3}\right)$ & $822.31(6)$ & $2075.7(2)$ & $4635.6(3)$ \\
\hline $\mathrm{Z}$ & 2 & 2 & 4 \\
\hline $\mathrm{T},(\mathrm{K})$ & 173(2) & $100(2)$ & $100(2)$ \\
\hline $\mathrm{D}_{\text {cald }}\left(\mathrm{g} \mathrm{cm}^{-3}\right)$ & 1.380 & 1.517 & 1.404 \\
\hline$\mu\left(\mathrm{mm}^{-1}\right)$ & 0.333 & 0.683 & 0.617 \\
\hline Min/Max transmission & $0.8929 / 0.9391$ & $0.8270 / 0.9450$ & $0.8470 / 0.9190$ \\
\hline Reflection collected & 10985 & 16151 & 50016 \\
\hline $\begin{array}{l}\text { Independent } \\
\text { reflections }\left[\mathrm{R}_{\mathrm{int}}\right]\end{array}$ & $4044[0.0254]$ & $7806[0.0662]$ & $10920[0.0501]$ \\
\hline
\end{tabular}




\begin{tabular}{|l|c|c|c|}
\hline Final R indices [I $>2 \sigma$ & $0.0370(0.0881)$ & $0.0570(0.0980)^{\mathrm{c}}$ & $0.0592(0.1357)^{\mathrm{d}}$ \\
$(\mathrm{I})]_{\mathrm{R} 1}^{\mathrm{a}}(w \mathrm{R} 2)^{\mathrm{b}}$ & & & \\
\hline Final R indices (all & $0.0511(0.0954)$ & $0.0842(0.1086)$ & $0.0773(0.1472)$ \\
data) R1(wR2) & & & \\
\hline
\end{tabular}

a) $\mathrm{R} 1=\left(\Sigma|| \mathrm{F}_{\mathrm{o}}|-| \mathrm{F}_{\mathrm{c}} \mid\right) / \Sigma\left|\mathrm{F}_{\mathrm{o}}\right|$, b) $\left.w \mathrm{R} 2=\left[\sum w\left(\mathrm{~F}_{\circ}{ }^{2}-\mathrm{F}_{\mathrm{c}}{ }^{2}\right)^{2} / \sum \mathrm{w}\left(\mathrm{F}_{\circ}{ }^{2}\right)^{2}\right]^{1 / 2} \mathrm{c}\right)$ Flack parameter $=$ $0.019(13)$, d) Flack parameter $=0.38(2)$

Table 2. Selected Bond Lengths $(\AA)$ for $\mathbf{1 a},[\mathrm{Cu}(\mathbf{2})]\left(\mathrm{BF}_{4}\right)_{2}$ and $[\mathrm{Cu}(\mathbf{3})]\left(\mathrm{BF}_{4}\right)_{2}$



\begin{tabular}{|c|c|c|c|c|c|}
\hline \multirow[t]{2}{*}{$\mathrm{Cu}-\mathrm{N}_{\mathrm{pyr}}$} & & Cu1-N1 & $1.980(5)$ & & \\
\hline & & $\mathrm{Cu} 1-\mathrm{N} 4$ & $2.123(6)$ & & \\
\hline \multirow[t]{2}{*}{$\mathrm{Cu}-\mathrm{N}_{\text {amine }}$} & & $\mathrm{Cu} 1-\mathrm{N} 2$ & $2.004(5)$ & $\mathrm{Cu} 1-\mathrm{N} 2$ & $2.032(6)$ \\
\hline & & $\mathrm{Cu} 1-\mathrm{N} 3$ & $1.990(6)$ & $\mathrm{Cu} 1-\mathrm{N} 3$ & $1.989(7)$ \\
\hline \multirow[t]{2}{*}{$\mathrm{P}-\mathrm{O}$} & P1-O1 $1.4857(12)$ & $\mathrm{P} 1-\mathrm{O} 1$ & $1.508(4)$ & $\mathrm{P} 1-\mathrm{O} 1$ & $1.500(5)$ \\
\hline & & $\mathrm{P} 2-\mathrm{O} 2$ & $1.484(5)$ & $\mathrm{P} 2-\mathrm{O} 4$ & $1.495(5)$ \\
\hline \multirow[t]{2}{*}{$\mathrm{N}-\mathrm{O}$} & & & & $\mathrm{N} 1-\mathrm{O} 2$ & $1.339(8)$ \\
\hline & & & & $\mathrm{N} 4-\mathrm{O} 3$ & $1.340(8)$ \\
\hline
\end{tabular}

$\mathrm{P}-\mathrm{C}\left(\mathrm{H}_{2}\right) \quad \mathrm{P} 1-\mathrm{C} 7 \quad 1.8215(16) \quad \mathrm{P} 1-\mathrm{C} 13 \quad 1.819(6)$

P2-C38 1.816(7)

$\mathrm{Cl}-\mathrm{C}\left(\mathrm{H}_{2}\right) \quad \mathrm{Cl1}-\mathrm{C} 1 \quad 1.7964(18)$ 


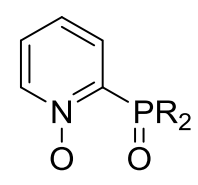

A

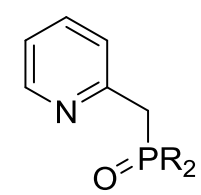

B

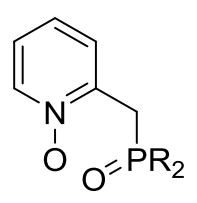

C



D

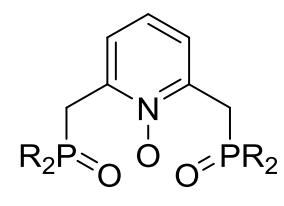

E

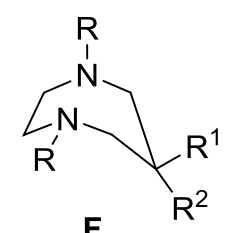

$\mathbf{F}$

Figure 1. Chelating phosphinopyridine and pyridine N-oxide ligand structure types A-E and the 1,4-diaza cycloheptane (DACH), F, platform. 


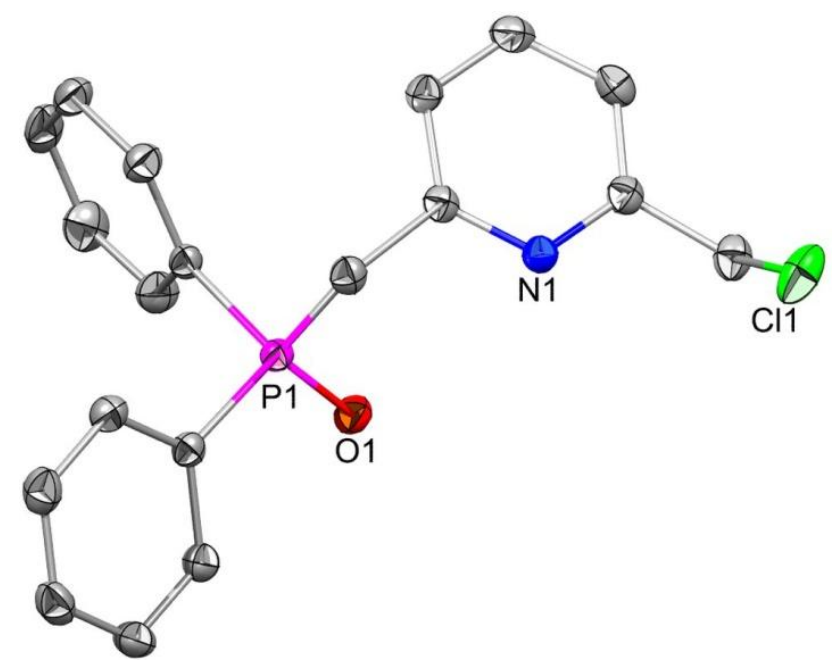

Figure 2. Molecular structure and atom labeling scheme for 1a with H-atoms omitted. Thermal ellipsoids are shown at the $50 \%$ level. 

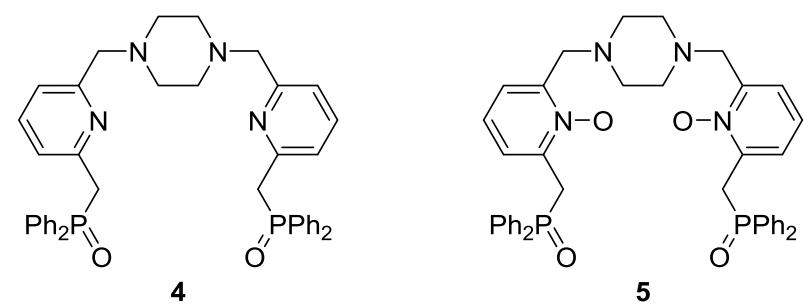

Figure 3. Model piperazine platform ligands 4 and $\mathbf{5}$. 
a)

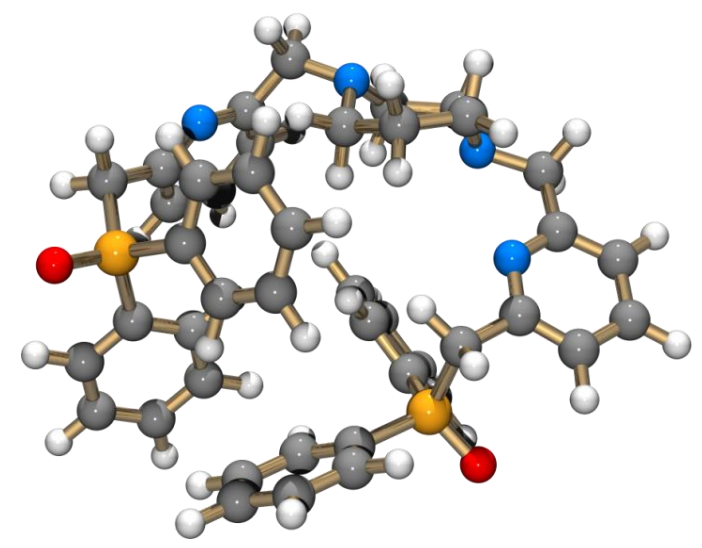

b)



c)

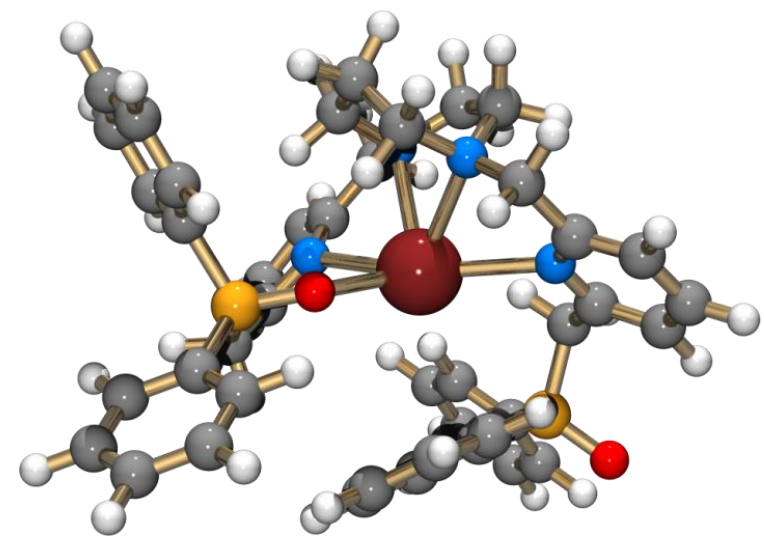

Figure 4. Computed geometry optimized lowest energy structure for a) 2, b) 1:1 hexadentate, $\mathrm{N}_{\mathrm{am}} \mathrm{N}_{\mathrm{am}} \mathrm{N}_{\text {pyr }} \mathrm{N}_{\text {pyr }} \mathrm{O}_{\mathrm{P}} \mathrm{O}_{\mathrm{P}}, \mathrm{Eu}(\mathrm{III})$ chelate complex, [ $\left.\mathrm{Eu}(2)^{3+}\right]$, and c) 1:1 pentadentate, $\mathrm{N}_{\mathrm{am}} \mathrm{N}_{\mathrm{am}} \mathrm{N}_{\mathrm{pyr}} \mathrm{N}_{\mathrm{pyr}} \mathrm{O}_{\mathrm{p}}, \mathrm{Eu}(\mathrm{III})$ chelate complex, [ $\left.\mathrm{Eu}(2)^{3+}\right]$. 
a)

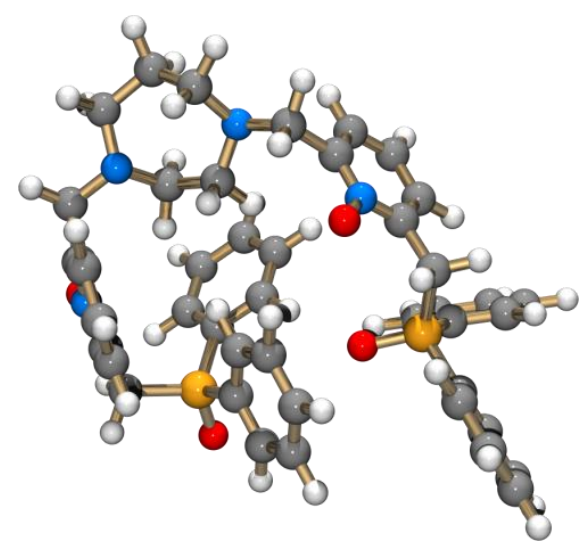

b)

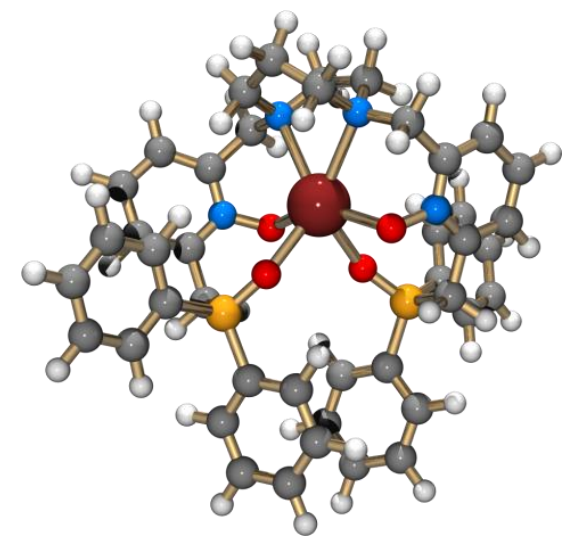

c)



Figure 5. Computed geometry optimized lowest energy structure for a) 3, b) 1:1 hexadentate, $\mathrm{N}_{\mathrm{am}} \mathrm{N}_{\mathrm{am}}$ $\mathrm{O}_{\mathrm{N}} \mathrm{O}_{\mathrm{N}} \mathrm{O}_{\mathrm{P}} \mathrm{O}_{\mathrm{P}}, \mathrm{Eu}(\mathrm{III})$ chelate complex, $\left[\mathrm{Eu}(3)^{3+}\right]$, and c) 1:1 pentadentate, $\mathrm{N}_{\mathrm{am}} \mathrm{N}_{\mathrm{am}} \mathrm{O}_{\mathrm{N}} \mathrm{O}_{\mathrm{N}} \mathrm{O}_{\mathrm{P}}, \mathrm{Eu}(\mathrm{III})$ chelate complex, $\left[\mathrm{Eu}(\mathbf{3})^{3+}\right]$. 


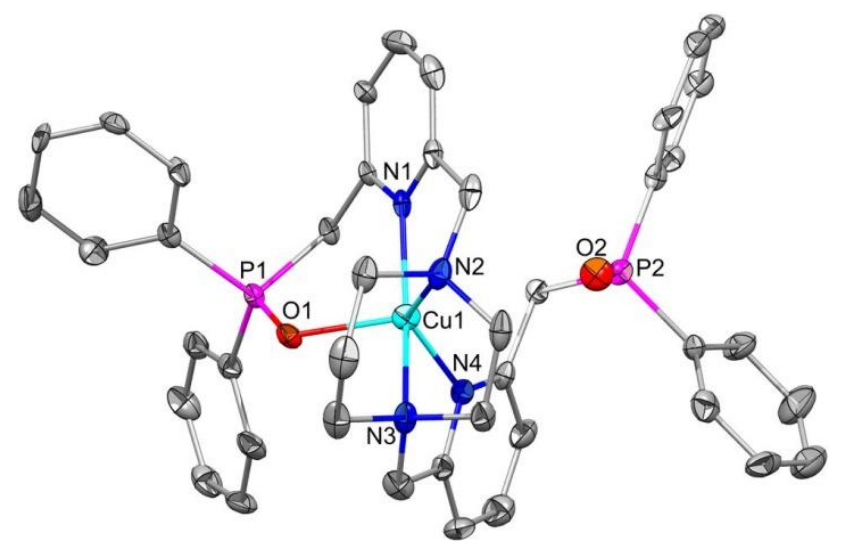

Figure6. Molecular structure and atom labeling scheme for $[\mathrm{Cu}(2)]\left(\mathrm{BF}_{4}\right)_{2}$ with $\mathrm{H}$-atoms omitted. Thermal ellipsoids are shown at the $50 \%$ level. 


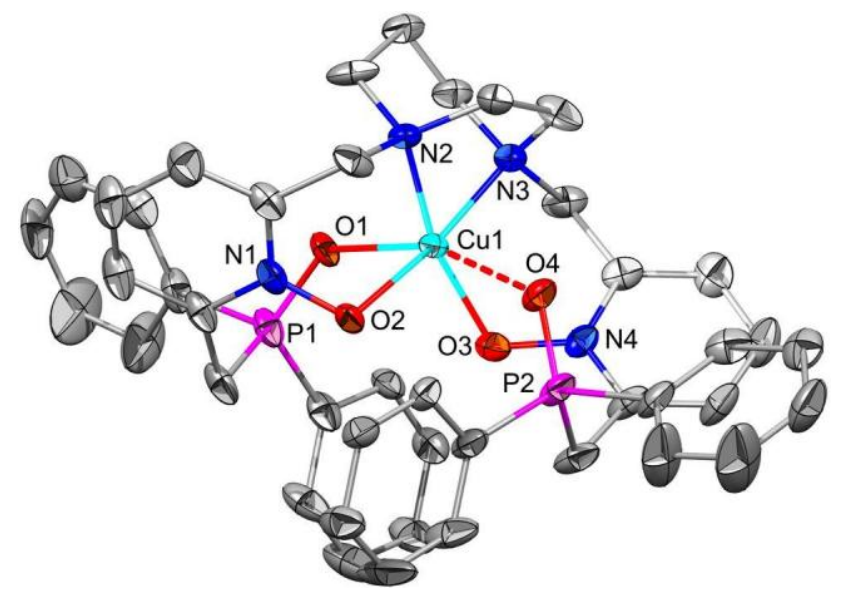

Figure 7. Molecular structure and atom labeling scheme for the cation, $\left[\mathrm{Cu}(\mathbf{3})^{2+}\right]$ in $[\mathrm{Cu}(\mathbf{3})]\left(\mathrm{BF}_{4}\right)_{2}$ with $\mathrm{H}$ atoms omitted. Thermal ellipsoids are shown at the $50 \%$ level. 


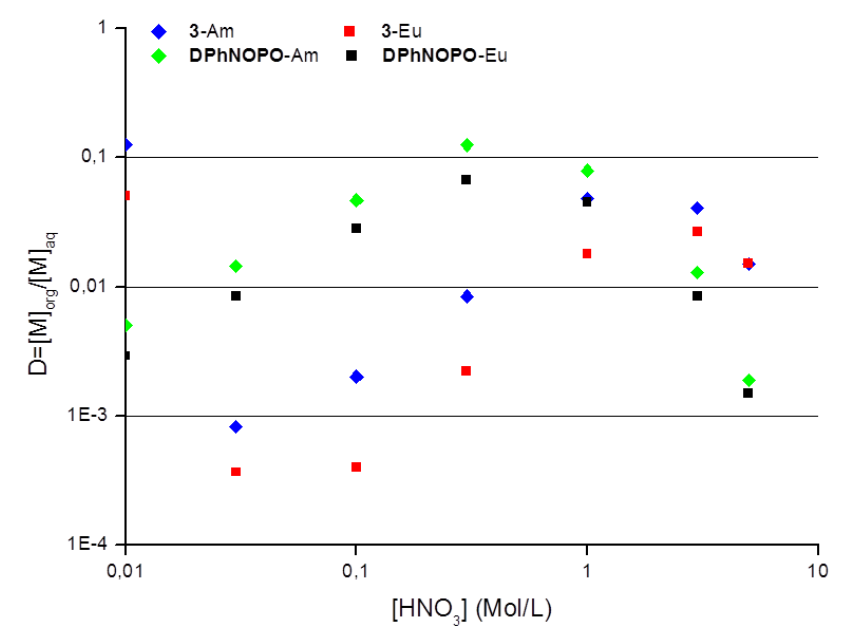

Figure 8. Americium(III) and europium(III) distribution ratios as a function of the initial nitric acid concentration. Organic phase: 3 and DPhNOPO at $10 \mathrm{mM}$ in 1,2 DCE. Aqueous phase: trace ${ }^{241} \mathrm{Am}$ and $0.1 \mathrm{mM}$ Europium nitrate in nitric acid. $\mathrm{O} / \mathrm{A}=1, \mathrm{~T}=25^{\circ} \mathrm{C}$. 